\title{
Thyroid Hormone Action
}

\section{IN VITRO CHARACTERIZATION OF SOLUBILIZED NUCLEAR RECEPTORS FROM RAT LIVER AND CULTURED GH CELLS $_{1}$}

\author{
Herbert H. Samuels, Jir S. Tsai, Juan Casanova, and \\ Frederick Stanley \\ From the Endocrine Division, Department of Medicine, New York University \\ Medical Center, New York 10016
}

A B STRACT We previously reported that putative nuclear receptors for thyroid hormone can be demonstrated by incubation of hormone either with intact $\mathrm{GH}_{1}$ cells, a rat pituitary tumor cell line, or with isolated $\mathrm{GH}_{1}$ cell nuclei and rat liver nuclei in vitro.

We characterized further the kinetics of triiodothyronine (T3) and thyroxine (T4) binding and the biochemical properties of the nuclear receptor after extraction to a soluble form with $0.4 \mathrm{M} \mathrm{KCl}$. In vitro binding of $\left[{ }^{125} \mathrm{I}\right] \mathrm{T} 3$ and $\left[{ }^{125} \mathrm{I}\right] \mathrm{T} 4$ with $\mathrm{GH}_{1}$ cell and rat liver nuclear extract was examined at $0^{\circ} \mathrm{C}$ and $37^{\circ} \mathrm{C}$. Equilibrium was attained within $5 \mathrm{~min}$ at $37^{\circ} \mathrm{C}$ and $2 \mathrm{~h}$ at $0^{\circ} \mathrm{C}$. The binding activity from $\mathrm{GH}_{1}$ cells was stable for at least $1 \mathrm{~h}$ at $37^{\circ} \mathrm{C}$ and 10 days at $-20^{\circ} \mathrm{C}$. Chromatography on a weak carboxylic acid column and inactivation by trypsin and Pronase, but not by DNase or RNase, suggested that the putative receptor was a nonhistone protein. The estimated equilibrium dissociation constants $\left(K_{d}\right)$ for hormone binding to the solubilized nuclear binding activity was $1.80 \times 10^{-10} \mathrm{M}$ (T3) and $1.20 \times 10^{-0} \mathrm{M}$ (T4) for $\mathrm{GH}_{1}$ cells and 1.57 $\times 10^{-10} \mathrm{M}$ (T3) and $2.0 \times 10^{-8} \mathrm{M}$ (T4) for rat liver. These $K_{d}$ values for $\mathrm{T} 3$ are virtually identical to those which we previously reported with isolated rat liver nuclei and $\mathrm{GH}_{1}$ cell nuclei in vitro.

The 10-fold greater affinity for T3 compared to T4 in the nuclear extract is also identical to that observed with intact $\mathrm{GH}_{1}$ cells. In addition, the $\left[{ }^{120} \mathrm{I}\right] \mathrm{T} 3$ and $\left[{ }^{120} \mathrm{I}\right] \mathrm{T} 4$ high-affinity binding in the nuclear extract were inhibited by either nonradioactive $\mathrm{T} 3$ or $\mathrm{T} 4$, which suggests that the binding activity in nuclear extract was identical for $\mathrm{T} 3$ and $\mathrm{T} 4$.

Dr. Samuels is the recipient of a PHS Research Career Development Award AM 46546.

Received for publication 28 February 1974 and in revised form 5 June 1974.
In contrast, the binding activity for $\mathrm{T} 4$ and $\mathrm{T} 3$ in $\mathrm{GH}_{1}$ cell cytosol was markedly different from that observed with nuclear extract $\left(K_{d}\right.$ values were $2.87 \times$ $10^{-10} \mathrm{M}$ for $\mathrm{T} 4$ and $1.13 \times 10^{-8} \mathrm{M}$ for $\mathrm{T} 3$ ).

Our results indicate that nuclear receptors for $\mathrm{T} 3$ and $\mathrm{T} 4$ can be isolated in a soluble and stable form with no apparent change in hormonal affinity. This should allow elucidation of the mechanisms of thyroid hormone action at the molecular level.

\section{INTRODUCTION}

The thyroid hormones regulate a wide variety of biological processes in virtually all tissues of higher organisms (1). Because of the significant effect of $\mathrm{L}$ thyroxine (T4) ${ }^{1}$ and L-triiodothyronine (T3) on stimulating tissue oxygen consumption, the mitochondria was long thought to be the primary locus of action of the thyroid hormones (2). The observations that the thyroid hormones play an important role in mammalian cell differentiation and growth, (3) and in amphibian metamorphosis (4) support the concept that the diverse biologic effects of these hormones may result from a primary effect on the control of gene expression (5).

We have previously reported that $\mathrm{T} 3$ and $\mathrm{T} 4$ induced a threefold increase in the rate of growth of $\mathrm{GH}_{1}$ cells, a rat pituitary tumor cell line, in culture (6). This effect occurred at physiologic hormone levels, and the estimated free hormone concentrations inducing a half-

${ }^{1}$ Abbreviations used in this paper: DNase, deoxyribonuclease $1 ; K_{d}$, equilibrium dissociation constant; RNase, ribonuclease A; STM buffer, $0.25 \mathrm{M}$ sucrose, $20 \mathrm{mM}$ Tris, 1.1 $\mathrm{mM} \mathrm{MgCl}, \mathrm{pH} 7.85$, at $25^{\circ} \mathrm{C}$; STM-Triton buffer, $0.25 \mathrm{M}$ sucrose, $20 \mathrm{mM}$ Tris, $1.1 \mathrm{MgCl}_{2}, 0.5 \%$ Triton X-100, $\mathrm{pH}$ 7.85 , at $25^{\circ} \mathrm{C}$; T3, L-triiodothyronine $\left(3,5,3^{\prime}\right.$-triiodo-L-thyronine); T4, L-thyroxine (3,5,3',5'-tetraiodo-L-thyronine). 
maximal biologic effect were $0.8 \times 10^{-11} \mathrm{M}$ for $\mathrm{T} 3$ and $1 \times 10^{-10} \mathrm{M}$ for T4 (6). Studies on the binding of $\left[{ }^{125} \mathrm{I}\right] \mathrm{T} 3$ and $\left[{ }^{125} \mathrm{I}\right] \mathrm{T} 4$ after incubation of hormone with intact cells demonstrated high-affinity saturable binding sites in the cell nucleus $(7,8)$. The estimated equilibrium dissociation constants $\left(K_{d}\right)$ were $2.9 \times 10^{-11} \mathrm{M}$ for $\mathrm{T} 3$ and $2.5 \times 10^{-10} \mathrm{M}$ for $\mathrm{T} 4(7,8)$. These affinities were sufficiently similar to the hormone concentrations that induced a half-maximal biologic effect to suggest that these nuclear binding activities functioned as receptors for the thyroid hormones.

This description of high-affinity saturable nuclear binding sites for the thyroid hormones in $\mathrm{GH}_{1}$ cells is similar in nature to the observations of Oppenheimer, Koerner, Schwartz, and Surks after injection of $\left[{ }^{125} \mathrm{I}\right] \mathrm{T} 3$ into intact rats (9).

We first reported that putative nuclear receptors for thyroid hormone could be demonstrated in vitro by incubation of $\left[{ }^{125} \mathrm{I}\right] \mathrm{T} 3$ directly with isolated nuclei of $\mathrm{GH}_{1}$ cells $(7,8)$ and rat liver $(10)$. The estimated $K_{d}$ for $\left[{ }^{125} \mathrm{I}\right] \mathrm{T} 3$ binding in vitro was $1.65 \times 10^{-10} \mathrm{M}$ for $\mathrm{GH}_{1}$ cell nuclei and $2.1 \times 10^{-10} \mathrm{M}$ for rat liver nuclei (10). The total number of estimated $\mathrm{T} 3$ binding sites per nucleus $(8,000)$, determined in vitro with $\mathrm{GH}_{1}$ cell nuclei and rat liver nuclei, were also identical to that determined by incubation of $\left.{ }^{[25} \mathrm{I}\right] \mathrm{T} 3$ with intact $\mathrm{GH}_{1}$ cells (10). This suggested that $\left[{ }^{125} \mathrm{I}\right] \mathrm{T} 3$ associated with the same nuclear binding moiety in whole cells as with isolated rat liver and $\mathrm{GH}_{1}$ cell nuclei in vitro.

Surks, Koerner, Dillman, and Oppenheimer reported that after injection of $\left[{ }^{125} \mathrm{I}\right] \mathrm{T} 3$ into rats the hormone that bound to nuclear sites in vivo could be dissociated as a hormone-macromolecular complex with $0.4 \mathrm{M}$ $\mathrm{KCl}$ (11). These investigators reported that the nuclear binding activity determined after in vivo injection of $\left[{ }^{120} \mathrm{I}\right] \mathrm{T} 3$ was a nonhistone protein (11). The nuclear binding activity once dissociated from nuclei, however, did not associate with $\left[{ }^{125} \mathrm{I}\right] \mathrm{T} 3$ in vitro (11).

We have extended our in vitro studies and have recently reported that $\left[{ }^{225} \mathrm{I}\right] \mathrm{T} 3$ can associate with saturable binding sites in nuclear extracts of $\mathrm{GH}_{1}$ cells, rat liver, and kidney in vitro (12). In this paper, we characterized the in vitro kinetics and affinity of $\mathrm{T} 3$ and T4 binding and the biochemical properties of the putative nuclear receptors after extraction to a soluble form with $0.4 \mathrm{M} \mathrm{KCl}$. Our results indicate that nuclear receptors for $\mathrm{T} 3$ and $\mathrm{T} 4$ can be isolated in a soluble and stable form and associate with thyroid hormone in vitro with no apparent change in hormonal affinity.

\section{METHODS}

Hormone analysis and purification. [ $\left.{ }^{180} \mathrm{I}\right] \mathrm{T} 3$ (initial sp act, $355 \mathrm{Ci} / \mathrm{mmol}$ ) and $\left[{ }^{185} \mathrm{I}\right] \mathrm{T} 4$ (initial sp act, $755 \mathrm{Ci} /$ mmol) were obtained from the Research Division, Abbott Laboratories, North Chicago, Ill. All radioactive analysis was determined with a gamma spectrometer. The purity of these compounds was examined by elution chromatography with Sephadex G-25 (fine) as previously described $(8,13)$. The columns, $0.9 \times 20 \mathrm{~cm}$, were equilibrated with $0.015 \mathrm{~N}$ $\mathrm{NaOH}-0.5 \mathrm{M} \mathrm{NaCl}$, and $0.3-0.5 \mathrm{ml}$ of hormone solution in $0.1 \mathrm{~N} \mathrm{NaOH}$ was applied to the column and then eluted over a 3-h period with $0.1 \mathrm{~N} \mathrm{NaOH}-5 \mathrm{mM} \mathrm{NaCl}$ at $25^{\circ} \mathrm{C}$. $\mathrm{W}$ ith this separation procedure, iodide eluted within one column volume, T3 eluted within the second column volume, and $\mathrm{T} 4$ eluted in the third column volume. The $\left.{ }^{185} \mathrm{I}\right] \mathrm{T} 3$ contained $1.5 \%$ iodide and no T4. The $\left[{ }^{100} \mathrm{I}\right] \mathrm{T} 4$ contained $96.2 \% \mathrm{~T} 4,2.3 \%$ iodide, and $1.5 \%$ T3. The [ $\left.{ }^{180} \mathrm{I}\right] \mathrm{T} 4$ was purified by two successive paper chromatographic procedures and used immediately after the last elution (14). After paper chromatography, the $\left.{ }^{125} \mathrm{I}\right] \mathrm{T} 4$ was examined with the Sephadex G-25 method and was found to be contaminated with less than $0.4 \%\left[{ }^{125} \mathrm{I}\right] \mathrm{T} 3$. The purity of the nonradioactive T3 and T4 (Sigma Chemical Co., St. Louis, Mo.) was examined by specific radioimmunoassay $(6,15)$. The T4 was contaminated by T3 (1.6\%) and was purified by paper chromatography (14) to decrease the extent of T3 contamination to less than $0.2 \%$. The T3 contained no T4 contamination.

Cell suspensions and media. $\mathrm{GH}_{1}$ cells were obtained from the American Type Culture Collection, Rockville, Md The cells were routinely grown in $95 \%$ air, $5 \% \mathrm{CO}_{2}$, with Ham's F-10 media supplemented to $15 \%$ with horse serum and to $2.5 \%$ with fetal calf serum (Grand Island Biological Co., Grand Island, N. Y.), as previously described (6).

To prepare for hormone binding studies, the media of cell cultures in the late logarithmic phase of growth was replaced with Ham's F-10 media supplemented to $10 \%$ with hypothyroid calf serum obtained from a thyroidectomized calf, Rockland Farms, Gilbertsville, $\mathrm{Pa}$. (6). The cell cultures were then incubated for an additional $36-48 \mathrm{~h}$ to deplete the cells of thyroid hormone (6). This was documented by incubating $\mathrm{GH}_{1}$ cells with media containing euthyroid concentrations of $\left[{ }^{125} \mathrm{I}\right] \mathrm{T} 3$ or $\left[{ }^{150} \mathrm{I}\right] \mathrm{T} 4$ for 2 days followed by a second incubation for $36-48 \mathrm{~h}$ with media containing $10 \%$ hypothyroid calf serum. The second incubation depleted the whole cells as well as the nuclei of $90 \%$ of the associated hormone.

Preparation of GH, cell nuclei and cytosol. The monolayer cultures were harvested with the aid of a rubber policeman and were centrifuged at $500 \mathrm{~g}$ for $5 \mathrm{~min}$. The cell pellet was then washed three times with $10 \mathrm{ml}$ of serum-free Ham's F-10 medium by repeated dispersion and centrifugation. All further procedures were carried out at $0-4^{\circ} \mathrm{C}$. The final cell pellet was homogenized in $10 \mathrm{vol}$ of STM buffer $\left(0.25 \mathrm{M}\right.$ sucrose, $20 \mathrm{mM}$ Tris, $1.1 \mathrm{mM} \mathrm{MgCl}_{2}$, $\mathrm{pH} 7.85$, at $25^{\circ} \mathrm{C}$ ) by 15 strokes at $5,000 \mathrm{rpm}$ with a motorized pestle (Tri-R Instruments, Inc., Rockville Centre, $\mathrm{N}$. Y.). The homogenate was then centrifuged at $800 \mathrm{~g}$ for $10 \mathrm{~min}$. The homogenate supernate was centrifuged at 105,$000 \mathrm{~g}$ for $90 \mathrm{~min}$ to prepare the cytosol fraction. Occasionally a top layer of lipid-like material was present after centrifugation. This was discarded, and the clear cytosol was stored at $4^{\circ} \mathrm{C}$ before use. The original homogenate pellet was used to prepare nuclei by two successive suspensions and centrifugations ( $800 \mathrm{~g}$ for $10 \mathrm{~min}$ ) in at least 10 vol of STM-Triton buffer (0.25 M sucrose, $20 \mathrm{mM}$

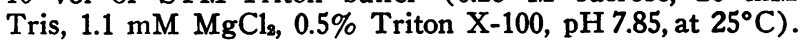
Triton X-100 was obtained from the Packard Instrument Co., Inc., Downers Grove, Ill. $\mathrm{GH}_{1}$ cell nuclei, prepared by 
the use of Triton X-100, contained less than $1 \%$ intact cells and were free of cytoplasmic contamination as estimated by phase contrast microscopy and staining with aceto-orcein. The high affinity saturable nuclear binding activity for T3 was not altered by isolation with Triton $\mathrm{X}-100$, and the magnitude of saturable binding was similar to nuclei isolated by centrifugation with $2.2 \mathrm{M}$ sucrose (8). The isolated $\mathrm{GH}_{1}$ cell nuclei had a protein/DNA ratio of approximately 2.0 and an RNA/DNA ratio of approximately 0.25 . In contrast, the protein/DNA ratio of whole cells was 10.0 and the RNA/DNA ratio was 2.0. The yield of nuclei was approximately $80-90 \%$ as estimated by DNA determination. Protein, DNA, and RNA were determined as previously described $(16,17,18) .1,000,000 \mathrm{GH}_{1}$ cells contain $13.0 \mu \mathrm{g}$ DNA.

Preparation of rat liver nuclei. Rat liver nuclei were prepared from hypothyroid Sprague-Dawley rats as previously described (10). Male rats, thyroidectomized approximately 8-12 wk before the study, were killed by subluxation of the cervical spine. Approximately $0.3-0.5 \mathrm{~g}$ of liver was excised, minced in $4^{\circ} \mathrm{C}$ STM buffer, homogenized in at least 10-15 vol of STM buffer at $5,000 \mathrm{rpm}$, and then centrifuged at $800 \mathrm{~g}$ for $10 \mathrm{~min}$. The homogenate pellet was suspended in STM-Triton buffer with a loose pestle at $2,000-3,000 \mathrm{rpm}$ and centrifuged again. This treatment with STM-Triton buffer was repeated two additional times. This procedure prepared rat liver nuclei free of cytoplasmic contamination and intact cells as determined by phase contrast microscopy and aceto-orcein staining (10). The rat liver nuclei had a protein/DNA ratio of approximately 3.0 and an RNA/DNA ratio of approximately $0.35(10,19)$. This compares to whole liver in which the protein/DNA ratio was approximately 30 , and the RNA/DNA ratio was 3.8 .

Conditions for solubilizing the nuclear-binding activity. To determine the optimal salt concentration for dissociation of the thyroid hormone binding activity from nuclei, intact $\mathrm{GH}_{1}$ cells were incubated with [ $\left.{ }^{125} \mathrm{I}\right] \mathrm{T} 3\left(1 \times 10^{-10} \mathrm{M}\right)$ with and without a 100-fold molar excess of nonradioactive T3 as previously described (8). After a 2-h incubation, the nuclei were prepared as described above. Expressed per $100 \mu \mathrm{g}$ DNA, the nuclei prepared from cells incubated with [ $\left.{ }^{120} \mathrm{I}\right] \mathrm{T} 3$ bound $80 \times 10^{-15} \mathrm{~mol}$ of $\left[{ }^{125} \mathrm{I}\right] \mathrm{T} 3$, and those prepared from cells incubated with a 100-fold molar excess of nonradioactive $\mathrm{T} 3$ bound $6.7 \times 10^{-15} \mathrm{~mol}$ of $\left.{ }^{125} \mathrm{I}\right] \mathrm{T} 3$. The nuclei were then incubated at $0^{\circ} \mathrm{C}$ in $2.0 \mathrm{ml}$ of extraction buffer $(0.25 \mathrm{M}$ sucrose, $20 \mathrm{mM}$ Tris, $1.1 \mathrm{mM} \mathrm{MgCl}, 5.0$ $\mathrm{mM}$ dithiothreitol, $\mathrm{pH} 7.85$, at $25^{\circ} \mathrm{C}$ ) and $\mathrm{KCl}$ ranging from 0.10 to $1.0 \mathrm{M}$. The nuclear suspensions were gently agitated every $5 \mathrm{~min}$ for $15 \mathrm{~min}$ and were then centrifuged at $6,000 \mathrm{~g}$ for $15 \mathrm{~min}$. The results of the extraction are illustrated in Fig. 1.

The extent of extraction of $\left[{ }^{125} \mathrm{I}\right] \mathrm{T} 3$ from nuclei prepared from cells that were incubated with a 100-fold molar excess of nonradioactive $\mathrm{T} 3$ was approximately $10 \%$ of the total bound $\left[{ }^{125} \mathrm{I}\right] \mathrm{T} 3$ at concentrations of $\mathrm{KCl}$ varying from 0.14 to $1.0 \mathrm{M}$. Application and elution of the $\left[{ }^{120} \mathrm{I}\right] \mathrm{T} 3$ with Sephadex G-25 (fine) columns as described below indicated that the hormone was unassociated with a macromolecule. In contrast, the $\mathrm{T} 3$ bound to nuclei prepared from cells incubated with only [ $\left.{ }^{120} \mathrm{I}\right] \mathrm{T} 3$ extracted readily with increasing $\mathrm{KCl}$ concentrations with approximately $60-65 \%$ of the total bound $\mathrm{T} 3$ extracted by $\mathrm{KCl}$ concentrations of 0.4 $\mathrm{M}$ or greater. Application and elution of these $\mathrm{KCl}$ extracts on Sephadex G-25 (fine) columns indicated that of the $\left[{ }^{185} \mathrm{I}\right] \mathrm{T} 3$ in the extract, approximately $85-90 \%$ was in a bound form.

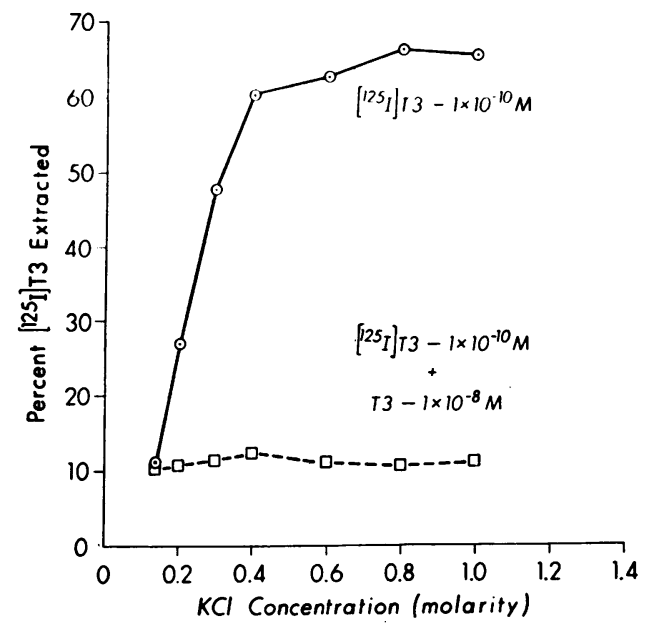

FIGURE 1 Extraction of bound [ $\left.{ }^{185} \mathrm{I}\right] \mathrm{T} 3$ from nuclei with $\mathrm{KCl}$. $\mathrm{GH}_{1}$ cells $\left(1 \times 10^{7}\right)$ were incubated in $10 \mathrm{ml}$ of serumfree Ham's F-10 media with $1 \times 10^{-10} \mathrm{M}\left[{ }^{125} \mathrm{I}\right] \mathrm{T} 3$ and with $1 \times 10^{-10} \mathrm{M}$ [ $\left.{ }^{120} \mathrm{I}\right] \mathrm{T} 3$ plus a 100 -fold molar excess of nonradioactive T3. After a 2 -h incubation at $37^{\circ} \mathrm{C}$, the nuclei were isolated and then incubated with extraction buffer containing various concentrations of $\mathrm{KCl}$. The results reflect the percent extraction of total bound $\left[{ }^{125} \mathrm{I}\right] \mathrm{T} 3$. The total [ ${ }^{125} \mathrm{I}$ ] T3 bound was $80 \times 10^{-15} \mathrm{~mol} / 100 \mu \mathrm{g}$ DNA after incubation with $1 \times 10^{-10} \mathrm{M}\left[{ }^{105} \mathrm{I}\right] \mathrm{T} 3$, and $6.7 \times 10^{-15} \mathrm{~mol} / 100$ $\mu \mathrm{g}$ DNA when incubated with a 100 -fold molar excess of nonradioactive T3.

The concentration chosen for extraction of the binding activity from $\mathrm{GH}_{1}$ cell nuclei was $0.4 \mathrm{M} \mathrm{KCl}$. This concentration permitted significant extraction of the nuclear binding activity, and the pellet formed after centrifugation was tightly packed. Higher $\mathrm{KCl}$ concentrations resulted in the formation of a viscous pellet which made separation of the supernate and pellet difficult. The binding activity was prepared from rat liver nuclei by using $0.4 \mathrm{M} \mathrm{KCl}$ with extraction buffer as described for $\mathrm{GH}_{1}$ cell nuclei. There was no observed difference in the magnitude of extracted nuclear binding activity when the extract was centrifuged at $6,000 \mathrm{~g}$ for $15 \mathrm{~min}$ or at $150,000 \mathrm{~g}$ for $3 \mathrm{~h}$. This suggested that the nuclear binding activity was in a soluble form.

It remained possible that the binding activity was being extracted from some whole cells or cytoplasmic elements which contaminated the nuclear preparation. In order to further exclude this possibility, we prepared nuclei with the method utilizing Triton $\mathrm{X}-100$ and then centrifuged the nuclear preparation thru $2.2 \mathrm{M}$ sucrose at $40,000 \mathrm{~g}$ for $1 \mathrm{~h}$ (8). With this procedure, any whole cells and nonnuclear cellular material would remain at the upper interface while only nuclei sediment to the bottom of the tube. Extraction of the nuclear pellet and the small amount of material in the upper phase with $0.4 \mathrm{M} \mathrm{KCl}$ and subsequent determination of binding activity as described below indicated that the thyroid hormone binding activity was extracted from nuclei rather than from whole cells or nonsoluble cytoplasmic elements. Incubation of nuclei with $0.4 \mathrm{M} \mathrm{KCl}$ extracted approximately $25-30 \%$ of the total nuclear protein and less than $2.0 \%$ of nuclear DNA and RNA.

Binding of $\left[{ }^{205} I\right] T 3$ and $\left[{ }^{125} I\right] T 4$ to $G H_{1}$ cell and rat liver nuclear extract in vitro. Nuclei prepared from approxi- 
mately $1 \times 10^{8} \mathrm{GH}_{1}$ cells or $0.3-0.5 \mathrm{~g}$ of rat liver was incubated with $5.0 \mathrm{ml}$ of extraction buffer (final $\mathrm{KCl}$ concentration, $0.4 \mathrm{M}$ ) at $0^{\circ} \mathrm{C}$, and the extract was prepared as described above. The incubation mixture contained 25-100 $\mu \mathrm{g}$ of extracted nuclear protein, $0.25 \mathrm{M}$ sucrose, $0.25 \mathrm{M}$ $\mathrm{KCl}, 20 \mathrm{mM}$ Tris, $1.1 \mathrm{MgCl}_{2}, 2.0 \mathrm{mM}$ NaEDTA, $5.0 \mathrm{mM}$ dithiothreitol, $\mathrm{pH} 7.85$, at $25^{\circ} \mathrm{C}$ in vol of $0.4 \mathrm{ml}$. [ $\left.{ }^{125} \mathrm{I}\right] \mathrm{T} 3$ or $\left.{ }^{125} \mathrm{I}\right] \mathrm{T} 4$ was added alone as well as in the presence of a molar excess (100-250-fold) of nonradioactive hormone in $0.05 \mathrm{ml}$ of STM buffer. The incubations were carried out at $0^{\circ} \mathrm{C}$ or at $37^{\circ} \mathrm{C}$ for various time intervals as indicated in the text. The magnitude of "specific" saturable hormone binding at a specific $\left[{ }^{125} \mathrm{I}\right]$ hormone concentration was considered to be that which was inhibited by the molar excess of nonradioactive hormone. Extraction buffer containing no nuclear extract served as a control.

The specificity of saturable hormone binding was examined by using $75 \mu \mathrm{g}$ of crystaline bovine serum albumin and $75 \mu \mathrm{g}$ of calf thymus type 11-A histone (Sigma Chemical Co.), which contains all histone fractions.

Binding of $\left.{ }^{185} I\right] T 3$ and $\left.{ }^{125} I\right] T 4$ to $G H_{1}$ cell cytosol in vitro. Binding of $\left[{ }^{125} \mathrm{I}\right] \mathrm{T} 3$ and $\left.{ }^{125} \mathrm{I}\right] \mathrm{T} 4$ with $\mathrm{GH}_{1}$ cell cytosol was determined as described for the $0.4 \mathrm{M} \mathrm{KCl}$ nuclear extract, except that $25-100 \mu \mathrm{g}$ of cytosol protein and no $\mathrm{KCl}$ was used in the incubation mixture. The binding reaction was studied at $0^{\circ} \mathrm{C}$.

Separation of bound and free hormone. For studies with nuclear extract or cytosol at $0^{\circ} \mathrm{C}$, the bound and free $\left.{ }^{[25} \mathrm{I}\right]$ hormone were quantitated after separation at $4^{\circ} \mathrm{C}$ on $0.9 \times 4.0-\mathrm{cm}$ columns $(2.5 \mathrm{ml})$ of Sephadex G-25 (fine) preswollen with STM buffer at $37^{\circ} \mathrm{C}$. The entire sample was applied to the column and then eluted with $1.5 \mathrm{ml}$ of $0^{\circ} \mathrm{C}$ STM buffer to separate the bound and free hormone. The separation was simplified by the fact that the free hormone rapidly binds to Sephadex $(12,13)$ which permits easy separation of the hormone bound to the nuclear or cytosol binding activity. The eluted bound hormone and the free hormone that remained on the column were quantitated with a gamma spectrometer. Trichloroacetic acid $(0.5 \mathrm{ml}$ of $3.0 \mathrm{M})$ was added to the eluted bound hormone fraction to precipitate protein. The eluted sample was then centrifuged at $8,000 \mathrm{~g}$ for $20 \mathrm{~min}$ to collect the protein precipitate for quantitation (16). Approximately $90 \%$ of the protein applied to the column was recovered in the eluted fraction. With control samples containing only extraction buffer, less than $0.4 \%$ of the ${ }^{125} \mathrm{I}$ radioactivity in the incubation mixture was eluted by $1.5 \mathrm{ml}$ of STM buffer. The percent of the total counts eluted $(0.2-0.4 \%)$ with the control buffer sample was constant for each experiment and remained linearly proportional to the $\left[{ }^{125} \mathrm{I}\right]$ hormone concentration. At concentrations of $\left[{ }^{125} \mathrm{I}\right]$ hormone below $1 \times 10^{-8} \mathrm{M}$, the magnitude of the ${ }^{125} \mathrm{I}$ radioactivity eluted in the control buffer sample was insignificant when compared to the eluted bound hormone. For example, with a concentration of $\left[{ }^{125} \mathrm{I}\right] \mathrm{T} 3$ or $\left[{ }^{125} \mathrm{I}\right] \mathrm{T} 4$ of $1 \times 10^{-8} \mathrm{M}$, the incubation mixture contained $4.5 \times 10^{-13} \mathrm{~mol}$ hormone $/ 0.45 \mathrm{ml}$. If $0.2 \%$ of the total radioactivity were eluted in the buffer control, this would be equivalent to $0.9 \times 10^{-15} \mathrm{~mol}$ hormone. By using Sephadex G-25 (fine), the addition of nonradioactive hormone to the [ $\left.{ }^{125} \mathrm{I}\right]$ hormone had no effect on the magnitude of elution of $\left[{ }^{125} \mathrm{I}\right]$ radioactivity either with the buffer control or with incubation mixtures containing bovine serum albumin or histone.

It should be noted that the magnitude of bound hormone is an estimated value and might vary depending on the method of separation of bound and free hormone. The
Sephadex column method for estimation of bound hormone can be utilized if the chromatography procedure does not result in the dissociation of bound hormone. Since the dissociation rate of the hormone-receptor complex is extremely slow at $0^{\circ} \mathrm{C}$ (Fig. 7), it seems unlikely that elution of bound hormone on Sephadex columns at $0^{\circ} \mathrm{C}$ would result in the dissociation of bound hormone. This was confirmed experimentally, in that the magnitude of bound hormone was identical if the sample was eluted 1 or 30 min after application to the column. This indicates that the Sephadex column environment does not appear to enhance the dissociation of bound $\left[{ }^{125} \mathrm{I}\right] \mathrm{T} 3$ and that the method likely gives a valid indication of the magnitude of bound hormone in the incubation mixture.

For kinetic studies of binding and dissociation at $37^{\circ} \mathrm{C}$, separation of bound from free hormone was determined as described for incubations at $0^{\circ} \mathrm{C}$, except that Sephadex G-25 (coarse) was used. This permitted rapid application of the sample to the column bed. After incubation at $37^{\circ} \mathrm{C}$, the sample was placed in an ice bath for $45 \mathrm{~s}$ and then applied to a Sephadex G-25 (coarse) column at $4^{\circ} \mathrm{C}$. The sample permeated the gel bed in approximately 30-45 s. The free hormone rapidly bound to the column, and at the temperature of $0-4^{\circ} \mathrm{C}$, dissociation of macromolecular bound hormone occurred at an extremely slow rate (Fig. 7), which permitted an estimation of the extent of binding at $37^{\circ} \mathrm{C}$. With control samples containing only extraction buffer, $1.0-1.5 \%$ of the total ${ }^{120} \mathrm{I}$ radioactivity was eluted by $1.5 \mathrm{ml}$ of STM buffer if the Sephadex G-25 (coarse) columns were prepared at least $2-4 \mathrm{~h}$ before use and the flow rate was no greater than $1.5 \mathrm{ml} / \mathrm{min}$. Occasionally for unknown reasons, unlike Sephadex G-25 (fine), a higher percent of radioactivity eluted with extraction buffer containing [125I]hormone compared to that which also contained a molar excess of nonradioactive hormone. Therefore, before use in a binding experiment, the percent of ${ }^{125} \mathrm{I}$ radioactivity eluted with $\left[{ }^{125} \mathrm{I}\right]$ hormone, as well as with a molar excess of nonradioactive hormone, was examined. The Sephadex G-25 (coarse) columns were used only if the eluted counts were identical.

Calculation of high-affinity and low-affinity hormone binding. The ${ }^{125} \mathrm{I}$ radioactivity eluted after incubation with nuclear extract or cytosol with a $\left.{ }^{125} \mathrm{I}\right]$ hormone concentration reflects binding to specific high-affinity saturable binding sites, "non-specific" low-affinity nonsaturable binding sites and unbound ${ }^{125} \mathrm{I}$ radioactivity which elutes from the column reflected by the buffer control.

The total hormone bound (high-affinity as well as lowaffinity) was determined by subtracting the [ $\left.{ }^{125} \mathrm{I}\right]$ hormone eluted with the buffer control containing an identical hormone concentration. The extent of [ $\left.{ }^{125} \mathrm{I}\right]$ hormone bound to low-affinity nonsaturable sites was calculated by first determining the magnitude of $\left[{ }^{125} \mathrm{I}\right]$ hormone binding in the presence of 200-250-fold molar excess of nonradioactive hormone and then subtracting the ${ }^{125} \mathrm{I}$ radioactivity eluted with a control sample containing only buffer with an identical $\left[{ }^{125} \mathrm{I}\right]$ hormone concentration. Higher concentrations of nonradioactive hormone had no effect on the estimated magnitude of low-affinity hormone binding.

The magnitude of specific high-affinity hormone binding was calculated by subtracting the low-affinity binding from the total hormone bound at a specific $\left[{ }^{125} \mathrm{I}\right]$ hormone concentration. Alternatively, the magnitude of specific highaffinity binding can also be determined without calculation of the low-affinity binding or the radioactivity eluted with the buffer control by determining the extent of inhibition 
of $\left[{ }^{125} \mathrm{I}\right]$ hormone binding by a molar excess of nonradioactive hormone.

The magnitude of low-affinity $\left[{ }^{125} I\right]$ hormone binding was linearly proportional to protein content and hormone concentration. At hormone concentrations less than $1 \times 10^{-9} \mathrm{M}$, the magnitude of low-affinity binding was less than $10 \%$ of the magnitude of high-affinity saturable binding. At the highest $\left[{ }^{120} \mathrm{I}\right]$ hormone concentration, e.g. $7.5 \times 10^{-0} \mathrm{M}\left[{ }^{125} \mathrm{I}\right]-$ $\mathrm{T} 4$, the low-affinity binding accounted for $50 \%$ of the eluted [ $\left.{ }^{120} \mathrm{I}\right] \mathrm{T} 4$. Therefore, for estimation of $K_{d}$, the extent of lowaffinity binding was determined and subtracted from the total hormone bound to determine the magnitude of high-affinity saturable hormone binding. This value was used in the estimation of the $K_{d}$ by the method of Scatchard (20).

Analysis of the ${ }^{125} I$ radioactivity bound to the nuclear extract and cytosol in vitro. The nature of the ${ }^{125} \mathrm{I}$ radioactivity bound to the nuclear extract and cytosol was examined after incubation with $\left[{ }^{125} \mathrm{I}\right] \mathrm{T} 3$ and $\left[{ }^{125} \mathrm{I}\right] \mathrm{T} 4$ in vitro. The sample was brought to $0.1 \mathrm{~N} \mathrm{NaOH}$ and then chromatographed with Sephadex G-25 (fine) as described in the section on Hormone Analysis and Purification.

The results indicated that with $\left[{ }^{125} \mathrm{I}\right] \mathrm{T} 3$, the bound ${ }^{125} \mathrm{I}$ radioactivity was greater than $98 \%$ [ $\left.{ }^{125} \mathrm{I}\right] \mathrm{T} 3$, and with [ $\left.{ }^{25} \mathrm{I}\right] \mathrm{T} 4$, the bound radioactivity was greater than $97 \%$ [25I]T4. In addition, a similar analysis of the total cytosol and nuclear extract incubation mixtures after a 2 -h incubation at $0^{\circ} \mathrm{C}$ demonstrated no deiodination of $\left[{ }^{125} \mathrm{I}\right] \mathrm{T} 3$ or conversion of $\left[{ }^{120} \mathrm{I}\right] \mathrm{T} 4$ to $\left[{ }^{125} \mathrm{I}\right] \mathrm{T} 3$. Therefore, the binding observed with $\left[{ }^{125} \mathrm{I}\right] \mathrm{T} 4$ represented $\mathrm{T} 4$ binding and not $\mathrm{T} 3$ binding as a result of conversion of $\mathrm{T} 4$ to $\mathrm{T} 3$.

Sensitivity of the muclear extract binding activity to cnzymic degradation. The sensitivity of the nuclear binding activity to enzymic degradation was determined with the incubation mixture described with the standard binding assay, along with $\left[{ }^{125} \mathrm{I}\right] \mathrm{T} 3\left(5 \times 10^{-10} \mathrm{M}\right)$, as well as with a 200-fold molar excess of nonradioactive T3. $\mathrm{GH}_{1}$ cell nuclear extracts were incubated for $30 \mathrm{~min}$ at $37^{\circ} \mathrm{C}$ with either $150 \mathrm{U}$ deoxyribonuclease 1 (DNase) $(3,100 \mathrm{U} / \mathrm{mg}$ ), $150 \mathrm{U}$ ribonuclease A (RNase) $(3,000 \mathrm{U} / \mathrm{mg}), 10 \mathrm{U}$ trypsin (197 U/mg), or $2.25 \mathrm{U}$ Pronase (45 proteolytic U/mg). DNase, RNase, and trypsin, all derived from bovine pancreas, were obtained from the Worthington Biochemical Corp., Freehold, N. J., and the Pronase was obtained from Calbiochem, San Diego, Calif. Extraction buffer and $\mathrm{GH}_{2}$ cell nuclear extract which received no enzyme served as controls. After incubation at $37^{\circ} \mathrm{C}$ the samples were transferred to an ice bath for $1 \mathrm{~h}$, and then the bound and free hormone were quantitated as described with G-25 (fine) columns.

Chromatography of the solubilized thyroid hormone binding activity on Bio-Rex 70 . To determine whether the [25 I] T3 in the $0.4 \mathrm{M} \mathrm{KCl}$ extract was bound to a histone or nonhistone protein, the bound $\left[{ }^{125} \mathrm{I}\right] \mathrm{T} 3$ was chromatographed at $0^{\circ} \mathrm{C}$ on a weak carboxylic acid column of BioRex 70 (200-400 mesh, sodium form) by the method of van den Broek, Noodén, Sevall, and Bonner (21). By elution at different $\mathrm{NaCl}$ concentrations, this procedure can separate histones from nonhistone nuclear proteins. Bio-Rex 70 was obtained from Bio-Rad Laboratories, Richmond, Calif.

After incubation of the $0.4 \mathrm{M} \mathrm{KCl}$ extract with [ $\left.{ }^{125} \mathrm{I}\right] \mathrm{T} 3$ $\left(2 \times 10^{-10} \mathrm{M}\right)$, the bound T3 was separated from the free T3 on a $0.9 \times 4.0-\mathrm{cm}$ Sephadex G-25 column (fine) that was equilibrated with $0.4 \mathrm{M} \mathrm{NaCl}-10 \mathrm{mM}$ Tris, $\mathrm{pH} 7.0$, at $25^{\circ} \mathrm{C}$. The eluted sample was applied to a $0.9 \times 5.0-\mathrm{cm}$ Bio-Rex 70 column that was equilibrated with $0.4 \mathrm{M} \mathrm{NaCl}-$

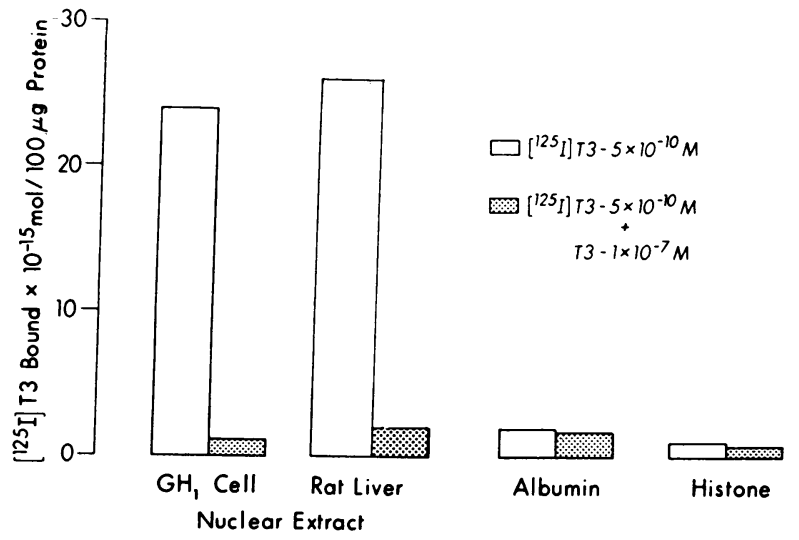

FJGURE 2 Binding of $\left[{ }^{125} \mathrm{I}\right] \mathrm{T} 3$ with $\mathrm{GH}_{1}$ cell and rat liver nuclear extract, albumin, and histone. $\mathrm{GH}_{1}$ cell nuclear extract (55 $\mu \mathrm{g}$ protein), rat liver nuclear extract (75 $\mu \mathrm{g}$ protein), crystalline bovine serum albumin (75 $\mu \mathrm{g}$ protein), histone ( $75 \mu \mathrm{g}$ protein), and a buffer control were incubated with the concentrations of $\mathrm{T} 3$ indicated in the figure. After a 2-h incubation at $0^{\circ} \mathrm{C}$, the bound and free hormone were separated as described in Methods. Each point reflects subtraction of the $\left[{ }^{125} \mathrm{I}\right] \mathrm{T} 3$ determined with the buffer control

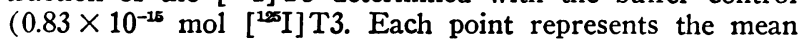
of three determinations. Each determination did not vary more than $10 \%$ from the mean.

$10 \mathrm{mM}$ Tris, $\mathrm{pH} 7.0$, at $25^{\circ} \mathrm{C}$. After sample application, to dissociate nonhistone proteins, the column was eluted with $0.4 \mathrm{M} \mathrm{NaCl}(15 \mathrm{ml} / \mathrm{h})$, and $0.5-\mathrm{ml}$ samples were collected. To dissociate histone proteins, the column was eluted with $1.0 \mathrm{M} \mathrm{NaCl}, 10 \mathrm{mM}$ Tris $\left(\mathrm{pH} 7.0\right.$, at $\left.25^{\circ} \mathrm{C}\right), 1.0 \mathrm{mM}$ $\mathrm{NaHSO}_{3}$, starting with fraction 21 at $15 \mathrm{ml} / \mathrm{h}$. Chromatography of the eluted $\left.{ }^{125} \mathrm{I}\right] \mathrm{T} 3$ on Sephadex G-25 (fine) indicated that the hormone remained associated with the binding activity after elution from the Bio-Rex 70 column.

\section{RESULTS}

Binding of $\left[{ }^{125} \mathrm{I}\right] T 3$ with nuclear extract, albumin, and histone. Fig. 2 compares the binding at $0^{\circ} \mathrm{C}$ of $\left.{ }^{125} \mathrm{I}\right] \mathrm{T} 3\left(5 \times 10^{-10} \mathrm{M}\right)$ with and without a 200 -fold molar excess of nonradioactive $\mathrm{T} 3$ to $\mathrm{GH}_{1}$ cell and rat liver nuclear extract, as well as bovine serum albumin and histone. Saturable hormone binding was only detected with the nuclear extracts. This illustrates a specificity of hormone binding with nuclear extract and that saturable T3 binding does not represent a general type of interaction with protein at this $\left[{ }^{125} \mathrm{I}\right] \mathrm{T} 3$ concentration.

Sensitivity to enzymic degradation. Fig. 3 illustrates the effect of trypsin, Pronase, RNase, and DNase on the solubilized nuclear binding activity of $\mathrm{GH}_{1}$ cells after incubation at $37^{\circ} \mathrm{C}$ for $30 \mathrm{~min}$. DNase and RNase had no effect on the magnitude of saturable $\left[{ }^{125} \mathrm{I}\right] \mathrm{T} 3$ binding, while Pronase and trypsin markedly inhibited the high-affinity T3 binding activity. The sensitivity 


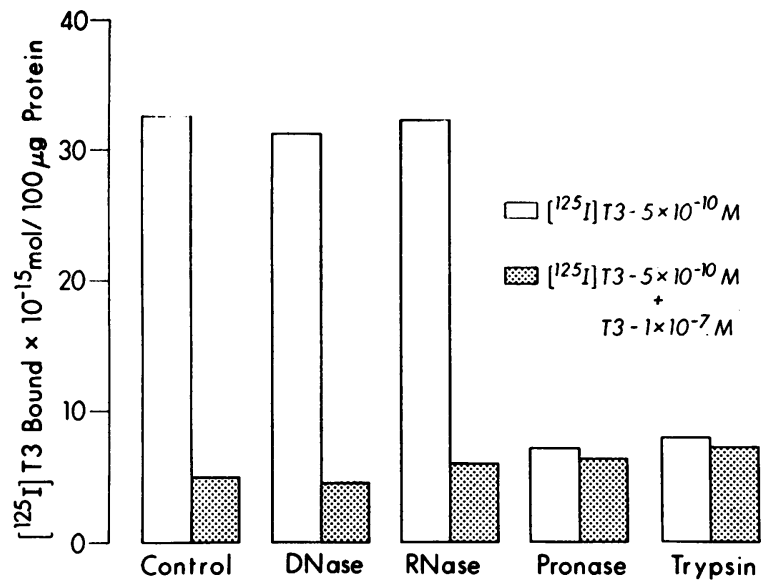

FIGURE 3 Sensitivity of the $\mathrm{GH}_{1}$ cell solubilized nuclear binding activity to enzymic degradation. [ $\left.{ }^{180} \mathrm{I}\right] \mathrm{T} 3\left(5 \times 10^{-10}\right.$ $\mathrm{M})$ and $\left[{ }^{125} \mathrm{I}\right] \mathrm{T} 3$ plus a 200 -fold molar excess of nonradioactive $\mathrm{T} 3$ were incubated with extraction buffer, $\mathrm{GH}_{1}$ cell nuclear extract (50 $\mu \mathrm{g}$ protein) alone, as well as with DNase $(150 \mathrm{U})$, RNase (150 U), Pronase (2.25 proteolytic $\mathrm{U})$ or trypsin $(10 \mathrm{U})$. The samples were incubated for 30 $\min$ at $37^{\circ} \mathrm{C}$ and then transferred to an ice bath for an additional $1 \mathrm{~h}$. The samples were then separated at $0^{\circ} \mathrm{C}$ with Sephadex G-25 (fine) as described in Methods. Each point reflects subtraction of the $\left[{ }^{125} \mathrm{I}\right] \mathrm{T} 3$ determined with the buffer control $\left(0.9 \times 10^{-15} \mathrm{~mol}\left[{ }^{120} \mathrm{I}\right] \mathrm{T} 3\right)$. Each point represents a mean of three determinations, and each determination did not vary more than $10 \%$ from the mean.

to enzymic hydrolysis suggests that the high-affinity nuclear binding activity is a protein moiety.

Chromatography of the solubilized GH cell nuclear binding activity on Bio-Rex 70. Previous studies indicated that incubation of nuclei with $0.4 \mathrm{M} \mathrm{KCl}$ dissociated predominately nonhistone nuclear proteins and only a part of the lysine-rich histone fraction (22). Surks et al. reported that the binding activity extracted after nuclear binding of $\left[{ }^{120} \mathrm{I}\right] \mathrm{T} 3$ in vivo was a nonhistone protein (11). This was based on a greater degree of extractability from nuclei at $\mathrm{pH} 8.5$ compared to $\mathrm{pH} 6.0$ and relatively less inactivation by trypsin compared to chymotrypsin and Pronase (11).

To examine the nature of the thyroid hormone nuclear binding activity in vitro, we chromatographed the binding activity after association with $\left[{ }^{205} \mathrm{I}\right] \mathrm{T} 3$ in vitro on a weak carboxylic acid column of Bio-Rex 70 (21). Nonhistone proteins elute from the column with $0.4 \mathrm{M}$ $\mathrm{NaCl}$, and histones elute at $1.0 \mathrm{M} \mathrm{NaCl}$. Fig. 4 illustrates that $0.4 \mathrm{M} \mathrm{NaCl}$ eluted a coincident [ [25 $\mathrm{I}] \mathrm{T} 3$ peak and protein peak. Application and elution of the radioactive peak on Sephadex G-25 (fine) columns indicated that the $\left[{ }^{125} \mathrm{I}\right] \mathrm{T} 3$ maintained its association with the binding activity. A protein or radioactive peak was not detected after elution of the column with $1.0 \mathrm{M}$ $\mathrm{NaCl}$. A similar study using $0.4 \mathrm{M} \mathrm{KCl}$ nuclear extract prepared after incubation of $\left[{ }^{205} \mathrm{I}\right] \mathrm{T} 3$ with intact cells showed identical results. These studies indicated that the binding activity determined both in vitro and after incubation of hormone with intact cells was likely not a histone protein. This observation, along with the fact that the binding activity was inactivated by trypsin and Pronase but not by DNase or RNase, suggested that the nuclear binding activity is a nonhistone protein.

Time-course of binding of $\left[{ }^{13} I\right] T 3$ to nuclear extract in vitro. Fig. 5 illustrates the time-course of binding of $\left[{ }^{125} \mathrm{I}\right] \mathrm{T} 3\left(5 \times 10^{-10} \mathrm{M}\right)$ with the nuclear extract of $\mathrm{GH}_{1}$ cells at $0^{\circ} \mathrm{C}$. The binding of $\left[{ }^{205} \mathrm{I}\right] \mathrm{T} 3$ in the presence of a 200 -fold molar excess of nonradioactive T3 markedly inhibited [ $\left.{ }^{1 \infty} \mathrm{I}\right] \mathrm{T} 3$ binding. The extent of inhibition by nonradioactive $\mathrm{T} 3$ reflects the magnitude of saturable binding at this $\left[{ }^{125} \mathrm{I}\right] \mathrm{T} 3$ concentration. The time-course of binding of $\left[{ }^{225} \mathrm{I}\right] \mathrm{T} 4$ was similar to that observed for $\left[{ }^{20} \mathrm{I}\right] \mathrm{T} 3$, and the binding kinetics of $\left[{ }^{125} \mathrm{I}\right] \mathrm{T} 3$ and $\left[{ }^{128} \mathrm{I}\right] \mathrm{T} 4$ were also similar with rat liver nuclear extract at $0^{\circ} \mathrm{C}$. The magnitude of $\left[{ }^{205} \mathrm{I}\right] \mathrm{T} 3$ binding after $20 \mathrm{~h}$ of incubation was virtually identical to the $100-\mathrm{min}$ incubation value in Fig. 5.

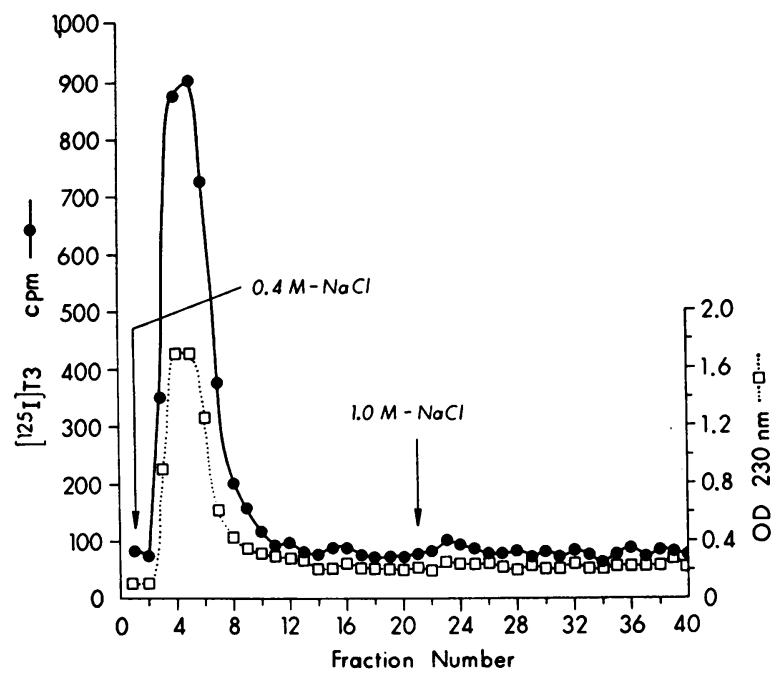

FIgURE 4 Chromatography of the solubilized $\mathrm{GH}_{1}$ cell nuclear binding activity on Bio-Rex 70 . Nuclear extract $(45$ $\mu \mathrm{g}$ protein) was incubated with [ $\left.{ }^{120} \mathrm{I}\right] \mathrm{T} 3\left(2 \times 10^{-10} \mathrm{M}\right)$ for $2 \mathrm{~h}$ at $0^{\circ} \mathrm{C}$. The bound [ $\left.{ }^{185} \mathrm{I}\right] \mathrm{T} 3$ was separated from the free [ $\left.{ }^{120} \mathrm{I}\right] \mathrm{T} 3$ with Sephadex G-25 (fine) columns equilibrated with $0.4 \mathrm{M} \mathrm{NaCl}-10 \mathrm{mM}$ Tris, $\mathrm{pH} 7.0$, at $25^{\circ} \mathrm{C}$. The eluted bound $\left[{ }^{125} \mathrm{I}\right] \mathrm{T} 3$ was then chromatographed on a column of Bio-Rex 70, as described in Methods. Over $90 \%$ of the radioactivity applied to the Bio-Rex column was recovered, and subsequent application of the $\left.{ }^{185} \mathrm{I}\right] \mathrm{T} 3$ eluted from the Bio-Rex column on Sephadex G-25 (fine) columns indicated that the $\left[{ }^{125} \mathrm{I}\right] \mathrm{T} 3$ remained associated to the binding activity. 
Fig. 6 illustrates the time-course of binding of [ $\left.{ }^{280} \mathrm{I}\right] \mathrm{T} 3\left(2 \times 10^{-10} \mathrm{M}\right)$ with nuclear extract of $\mathrm{GH}_{1}$ cells at $37^{\circ} \mathrm{C}$. Binding of $\mathrm{T} 3$ occurred very rapidly, and equilibrium was attained within $5 \mathrm{~min}$ of incubation. The magnitude of the $\left[{ }^{120} \mathrm{I}\right] \mathrm{T} 3$ binding remained constant during the $1 \mathrm{~h}$ incubation at $37^{\circ} \mathrm{C}$. This indicated that the nuclear binding activity was relatively stable at $37^{\circ} \mathrm{C}$ under the conditions of incubation. The solubilized nuclear binding activity from $\mathrm{GH}_{1}$ cells was also stable for at least $2 \mathrm{wk}$ when stored at $-20^{\circ} \mathrm{C}$. In addition, the magnitude of $\left[{ }^{125} \mathrm{I}\right] \mathrm{T} 3$ saturable binding was identical if the $\mathrm{GH}_{1}$ cell nuclear extract was incubated for $2 \mathrm{~h}$ at $0^{\circ} \mathrm{C}$ or first incubated at $37^{\circ} \mathrm{C}$ for 15 $\min$ and then for an additional $2 \mathrm{~h}$ at $0^{\circ} \mathrm{C}$. This indicated that $\left[{ }^{205} \mathrm{I}\right] \mathrm{T} 3$ associated with the same binding activity at both incubation temperatures.

In contrast, the binding of $\left[{ }^{125} \mathrm{I}\right] \mathrm{T} 3$ with nuclear extract of rat liver demonstrated somewhat different binding kinetics. The binding of $\left[{ }^{125} \mathrm{I}\right] \mathrm{T} 3$ also attained equilibrium within $5 \mathrm{~min}$ of incubation at $37^{\circ} \mathrm{C}$ but decreased to $60 \%$ of the 5 -min value after $60 \mathrm{~min}$ of incubation. This suggested that some proteolytic activity was present in the rat liver extract but not in $\mathrm{GH}_{1}$ cell nuclear extract.

Dissociation of $\left[{ }^{205} I\right] T 3$ bound to the $G H_{1}$ cell nuclear binding activity. Fig. 7 illustrates the rate of dissociation of bound $\left[{ }^{125} \mathrm{I}\right] \mathrm{T} 3$ at 0 and $37^{\circ} \mathrm{C}$. $\left[{ }^{125} \mathrm{I}\right] \mathrm{T} 3(5 \times$

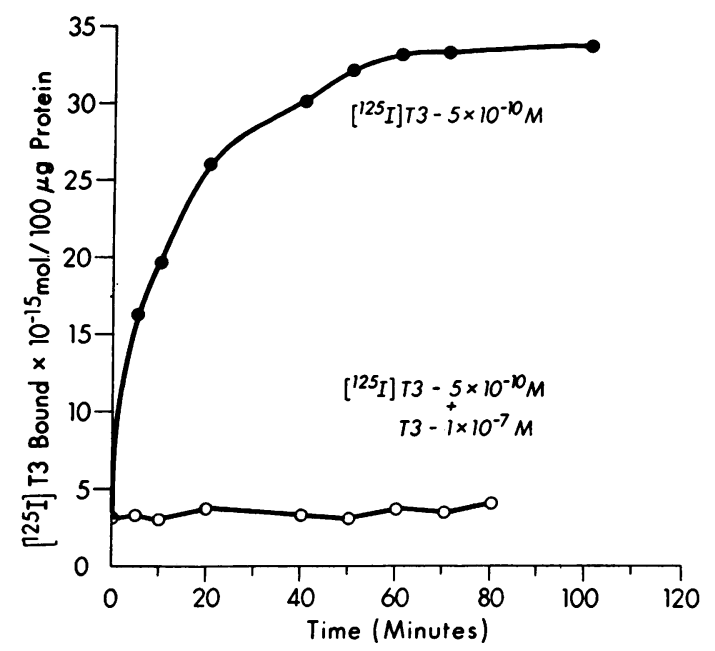

FIgURE 5 Time-course of binding of [ $\left.{ }^{125} \mathrm{I}\right] \mathrm{T} 3$ to $\mathrm{GH}_{1}$ cell nuclear extract at $0^{\circ} \mathrm{C} . \mathrm{GH}_{1}$ cell nuclear extracts $(70 \mu \mathrm{g}$ protein) and buffer controls were incubated with [ $\left.{ }^{150} \mathrm{I}\right] \mathrm{T} 3$ $\left(5 \times 10^{-10} \mathrm{M}\right)$ as well as with [ $\left.{ }^{100} \mathrm{I}\right] \mathrm{T} 3$ plus a 200 -fold molar excess of nonradioactive T3. The samples were incubated at $0^{\circ} \mathrm{C}$, and at the indicated times, the bound $\left[{ }^{120} \mathrm{I}\right] \mathrm{T} 3$ was determined as described in Methods. Each point reflects subtraction of the [ $\left.{ }^{120} \mathrm{I}\right]$ hormone radioactivity determined with the buffer control $\left(1.1 \times 10^{-15} \mathrm{~mol}\right.$ [ $\left.\left.{ }^{155} \mathrm{I}\right] \mathrm{T} 3\right)$. Each point reflects the mean of three determinations, and each determination did not vary more than $10 \%$ from the mean.

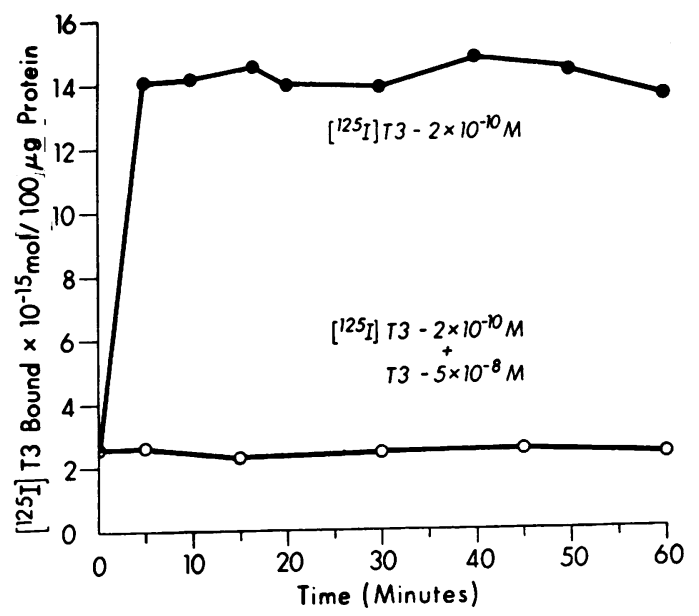

Figure 6 Time-course of binding of $\left[{ }^{125} \mathrm{I}\right] \mathrm{T} 3$ to $\mathrm{GH}_{1}$ cell nuclear extract at $37^{\circ} \mathrm{C} . \mathrm{GH}_{1}$ cell nuclear extracts (60 $\mu \mathrm{g}$ protein) and buffer controls were incubated with [180 I] T3 $\left(2 \times 10^{-10} \mathrm{M}\right)$ as well as with $\left[{ }^{120} \mathrm{I}\right] \mathrm{T} 3$ plus a 250 fold molar excess of nonradioactive T3. The samples were incubated at $37^{\circ} \mathrm{C}$, and at the indicated times, the bound [25I]T3 was determined as described in Methods. Each point reflects subtraction of the $\left[{ }^{125} \mathrm{I}\right]$ hormone determined with the buffer control $\left(1.5 \times 10^{-15} \mathrm{~mol}\right.$ [ $\left.\left.{ }^{125} \mathrm{I}\right] \mathrm{T} 3\right)$. Each point reflects the mean of three determinations, and each determination did not vary more than $12 \%$ from the mean.

$10^{-10} \mathrm{M}$ ) was preincubated with $\mathrm{GH}_{1}$ cell nuclear extract at $37^{\circ} \mathrm{C}$ for $15 \mathrm{~min}$ and at $0^{\circ} \mathrm{C}$ for $2 \mathrm{~h}$. At time 0 indicated on the figure, T3 was added in $5 \mu 1$ of STM buffer to achieve a 100 -fold molar excess of nonradioactive hormone. This rapidly decreased the specific activity of the free $\left[{ }^{225} \mathrm{I}\right] \mathrm{T} 3$ and limited detectable reassociation of $\left[{ }^{120} \mathrm{I}\right] \mathrm{T} 3$ to saturable binding sites, permitting the detection of the dissociation of bound $\left.{ }^{120} \mathrm{I}\right] \mathrm{T} 3$. At $0^{\circ} \mathrm{C}$, no significant dissociation was noted during the $80 \mathrm{~min}$ incubation after addition of nonradioactive T3. Further incubation demonstrated a half time of dissociation of $14 \mathrm{~h}$ at $0^{\circ} \mathrm{C}$. This indicated that the binding determined after $100 \mathrm{~min}$ of incubation (Fig. 5) represented an equilibrium value, since no further binding occurred after $20 \mathrm{~h}$ of incubation, during which time a significant exchange of bound hormone occurs. In contrast, at $37^{\circ} \mathrm{C}$, the dissociation rate was extremely rapid with virtually complete dissociation of the $\left[{ }^{128} \mathrm{I}\right] \mathrm{T} 3$ bound to saturable sites within $5 \mathrm{~min}$ of incubation. The magnitude of $\left.{ }^{125} \mathrm{I}\right] \mathrm{T} 3$ binding $5 \mathrm{~min}$ after addition of nonradioactive T3 was approximately $10 \times 10^{-15} \mathrm{~mol}$ of $\left[{ }^{125} \mathrm{I}\right] \mathrm{T} 3$ bound/ $100 \mu \mathrm{g}$ protein. This value is very similar to the estimated magnitude of high-capacity low-affinity binding determined by incubation of the extract with a 10Gfold molar excess of nonradioactive $\mathrm{T} 3$ at the beginning of the experiment $\left(7 \times 10^{-15} \mathrm{~mol}\right.$ of $\left[{ }^{125} \mathrm{I}\right] \mathrm{T} 3$ bound $/ 100$ $\mu \mathrm{g}$ protein). This indicates that the bound $\left[{ }^{125} \mathrm{I}\right] \mathrm{T} 3 \mathrm{de}-$ 


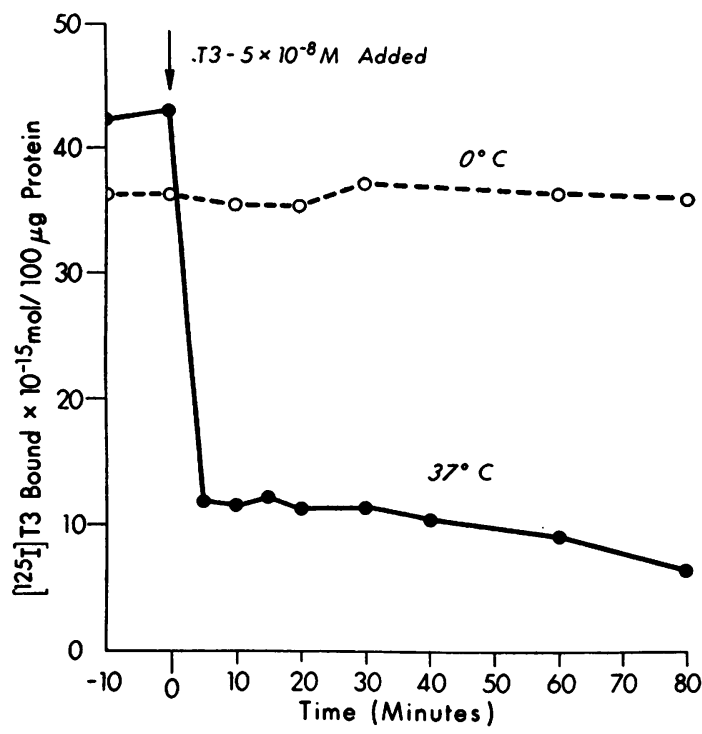

Figure 7 Dissociation of $\left.{ }^{125} \mathrm{I}\right] \mathrm{T} 3$ bound to $\mathrm{GH}_{1}$ cell nuclear extract in vitro. [ $\left.{ }^{125} \mathrm{I}\right] \mathrm{T} 3\left(5 \times 10^{-10} \mathrm{M}\right)$ was preincubated with $\mathrm{GH}_{1}$ cell nuclear extracts for $15 \mathrm{~min}$ at $37^{\circ} \mathrm{C}$ and for $2 \mathrm{~h}$ at $0^{\circ} \mathrm{C}$. $10 \mathrm{~min}$ before the addition of nonradioactive $\mathrm{T} 3$, the magnitude of total bound $\left[{ }^{125} \mathrm{I}\right] \mathrm{T} 3$ was determined as described in Methods. At time zero, T3 was added in $5 \mu 1$ of STM buffer to achieve a 100 -fold molar excess of nonradioactive T3. At the indicated times, the magnitude of bound $\left.{ }^{125} \mathrm{I}\right] \mathrm{T} 3$ at $0^{\circ} \mathrm{C}$ and $37^{\circ} \mathrm{C}$ were determined with Sephadex G-25 (fine) and Sephadex G-25 (coarse) columns, respectively. The extent of low-affinity binding was determined (not illustrated) by incubating the extracts and a buffer control with $5 \times 10^{-10} \mathrm{M}\left[{ }^{125} \mathrm{I}\right] \mathrm{T} 3$ plus a 100-fold molar excess of nonradioactive T3 at the beginning of the experiment. The magnitude of low-affinity [20I] T3 binding was $5 \times 10^{-15} \mathrm{~mol} / 100 \mu \mathrm{g}$ protein at $4^{\circ} \mathrm{C}$ and $7 \times 10^{-15} \mathrm{~mol} / 100 \mu \mathrm{g}$ protein at $37^{\circ} \mathrm{C}$. Each point represents the mean of three determinations, and each point did not vary more than $10 \%$ from the mean.

termined $5 \mathrm{~min}$ after addition of nonradioactive $\mathrm{T} 3$ reflects association with low affinity nonspecific binding sites. Addition of $5 \mu 1$ of STM buffer without T3 to control samples had no effects on the magnitude of bound [ $\left.{ }^{105} \mathrm{I}\right] \mathrm{T} 3$.

The very slow dissociation rate at $0^{\circ} \mathrm{C}$ suggests that the binding of $\left[{ }^{205} \mathrm{I}\right] \mathrm{T} 3$ observed with $\mathrm{GH}_{1}$ cell nuclear extract after a 2-h incubation reflects binding of hormone to nuclear sites unoccupied before nuclear isolation. In contrast, binding of $\left[{ }^{20} \mathrm{I}\right] \mathrm{T} 3$ at $37^{\circ} \mathrm{C}$ should estimate the total number of binding sites, those unoccupied and those occupied before nuclear isolation, due to the rapid rates of association and dissociation. As mentioned previously, an identical number of saturable $\left[{ }^{20} \mathrm{I}\right] \mathrm{T} 3$ binding sites was determined if the $\mathrm{GH}_{1}$ cell nuclear extract was incubated either for $2 \mathrm{~h}$ at $0^{\circ} \mathrm{C}$ or first incubated at $37^{\circ} \mathrm{C}$ for $15 \mathrm{~min}$ and then for an additional $2 \mathrm{~h}$ at $0^{\circ} \mathrm{C}$. This is probably due to the fact that the cells were depleted of thyroid hormone with hypothyroid calf serum and the nuclear binding sites were unoccupied with hormone before nuclear isolation.

Relation of high-affinity binding of $\left[{ }^{135} \mathrm{I}\right] \mathrm{T} 3$ with the protein content of the GH. cell nuclear extract in vitro. $\mathrm{GH}_{1}$ cell nuclear extract equivalent to $25,50,75$, and $100 \mu \mathrm{g}$ protein was incubated with $\left[{ }^{205} \mathrm{I}\right] \mathrm{T} 3\left(5 \times 10^{-10}\right.$ $M)$ as well as with a 200 -fold molar excess of nonradioactive $\mathrm{T} 3$ at $0^{\circ} \mathrm{C}$ to quantitate the extent of saturable binding at each protein concentration. The results are illustrated in Fig. 8 and indicate a linear relationship of saturable hormone binding to the protein content of the nuclear extract.

Estimation of the $K_{d}$ for $\left[{ }^{125} I\right] T 3$ and $\left[{ }^{135} I\right] T 4$ binding with nuclear extract of $\mathrm{GH}_{1}$ cells and rat liver. We have previously reported that the total number of nuclear binding sites were similar after incubation of [20I]T3 with intact $\mathrm{GH}_{1}$ cells or with isolated $\mathrm{GH}_{1}$ cell nuclei or rat liver nuclei in vitro (10). The estimated $K_{\alpha}$ for $\left[{ }^{25} \mathrm{I}\right] \mathrm{T} 3$ binding in vitro was $1.65 \times 10^{-10}$ $\mathrm{M}$ for isolated $\mathrm{GH}_{1}$ cell nuclei and $2.1 \times 10^{-10} \mathrm{M}$ for isolated rat liver nuclei (10). The estimated $K_{d}$ for T3 binding with isolated nuclei was similar at 0 and $37^{\circ} \mathrm{C}$.

To determine whether the binding activity demonstrated with solubilized nuclear extract was similar to that determined with isolated nuclei in vitro, we estimated the $K_{d}$ for $\left[{ }^{125} \mathrm{I}\right] \mathrm{T} 3$ and $\left[{ }^{205} \mathrm{I}\right] \mathrm{T} 4$ binding to nu-

${ }^{2}$ Samuels, H. H., and J. S. Tsai. Unpublished observation.

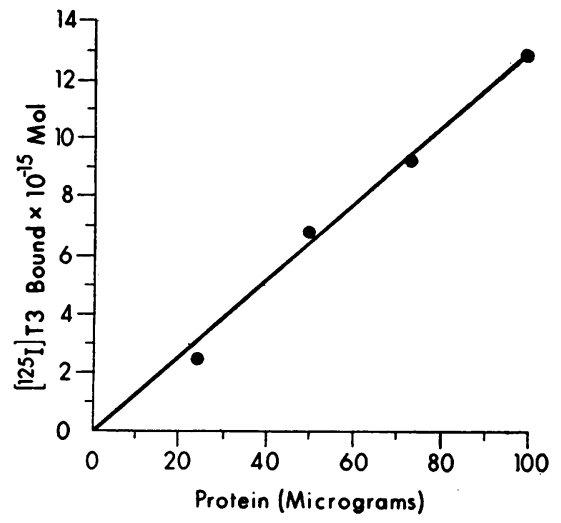

FIGURE 8 Relation of saturable binding of $\left[{ }^{120} \mathrm{I}\right] \mathrm{T} 3$ to the protein content of the $\mathrm{GH}_{1}$ cell nuclear extract in vitro. $\mathrm{GH}_{1}$ cell nuclear extracts equivalent to $25,50,75$, and $100 \mu \mathrm{g}$ protein were each incubated with [ $\left.{ }^{120} \mathrm{I}\right] \mathrm{T} 3\left(5 \times 10^{-10} \mathrm{M}\right)$ as well as with $\left[{ }^{120} \mathrm{I}\right] \mathrm{T} 3$ plus a 200 -molar excess of nonradioactive T3. After a $2-\mathrm{h}$ incubation at $0^{\circ} \mathrm{C}$, the bound hormone was quantitated, and the magnitude of saturable binding at each protein concentration was determined by the extent of inhibition by nonradioactive T3. Each point represents the mean of three determinations, and each determination did not vary more than $12 \%$ from the mean. 
clear extract at $0^{\circ} \mathrm{C}$. The binding was studied at $0^{\circ} \mathrm{C}$ to minimize proteolytic activity in the rat liver nuclear extract in order to compare the hormonal affinities with those of $\mathrm{GH}_{1}$ cell nuclear extract.

Fig. 9 illustrates an estimation of the $K_{d}$ for $\left[{ }^{125} \mathrm{I}\right] \mathrm{T} 3$ and $\left[{ }^{125} \mathrm{I}\right] \mathrm{T} 4$ binding to $\mathrm{GH}_{1}$ cell nuclear extract by the method of Scatchard after a 2 -h incubation at $0^{\circ} \mathrm{C}$ (20). The $K_{d}$ for hormone binding with the $\mathrm{GH}_{1}$ cell nuclear extract was estimated to be $1.8 \times 10^{-10} \mathrm{M}$ for $\left[{ }^{125} \mathrm{I}\right] \mathrm{T} 3$ and $1.2 \times 10^{-9} \mathrm{M}$ for $\left[{ }^{125} \mathrm{I}\right] \mathrm{T} 4$. Fig. 10 illustrates a similar experiment with rat liver nuclear extract. The estimated $K_{d}$ was $1.57 \times 10^{-10} \mathrm{M}$ for $\left[{ }^{125} \mathrm{I}\right] \mathrm{T} 3$ and $2.0 \times 10^{-0} \mathrm{M}$ for $\left[{ }^{125} \mathrm{I}\right] \mathrm{T} 4$. In both nuclear extracts, the affinity of T4 binding was approximately 1/10th that of T3. This difference in affinity agrees very well with our observations with intact $\mathrm{GH}_{1}$ cells in which T4 has $1 / 10$ th the intrinsic biologic activity of T3 (6) as well as $1 / 10$ th the affinity for high-affinity nuclear binding sites $(7,8)$. The estimated $K_{d}$ for $\left[{ }^{125} \mathrm{I}\right] \mathrm{T} 3$ binding with the solubilized nuclear binding activity of $\mathrm{GH}_{1}$ cells and rat liver are also virtually identical to the $K_{d}$ estimated with isolated $\mathrm{GH}_{1}$ cell and rat liver nuclei in vitro (10). Although the number of binding sites for $\mathrm{T} 3$ and $\mathrm{T} 4$ appeared to be identical for rat liver nuclear extract, the $\mathrm{T} 3$ and $\mathrm{T} 4$ binding curves did not always intersect at precisely the same point (Fig. 9). This might suggest that $\mathrm{T} 3$ and $\mathrm{T} 4$ bind to dissimilar binding moieties in the nuclear extract.

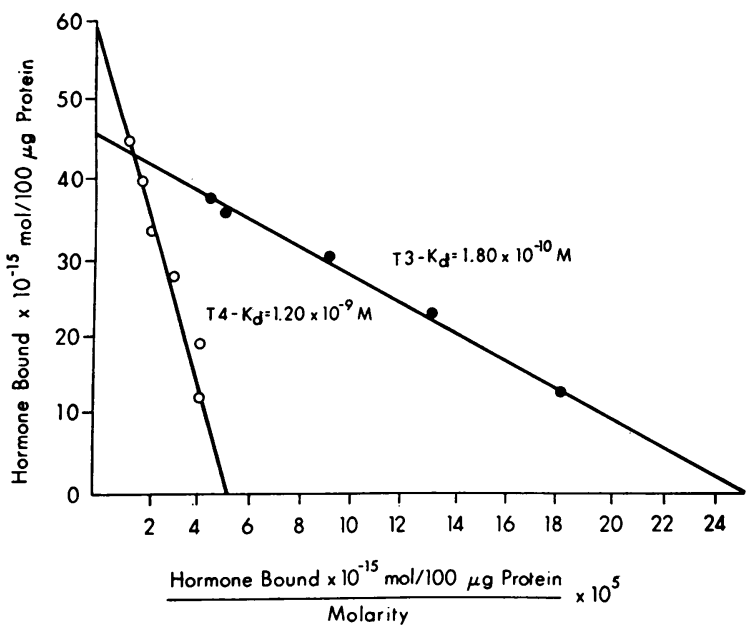

FIGURE 9 Scatchard analysis of binding of $\left.{ }^{125} \mathrm{I}\right] \mathrm{T} 3$ and [ $\left.{ }^{125} \mathrm{I}\right] \mathrm{T} 4$ with $\mathrm{GH}_{1}$ cell nuclear extract in vitro. Nuclear extracts of $\mathrm{GH}_{1}$ cells (45 $\mu \mathrm{g}$ protein) were incubated with various concentrations of $\left.{ }^{125} \mathrm{I}\right] \mathrm{T} 3$ and $\left[{ }^{125} \mathrm{I}\right] \mathrm{T} 4$. Nuclear extract at each $\left[{ }^{125} \mathrm{I}\right]$ hormone concentration was also incubated with a 200 -fold molar excess of the respective nonradioactive hormone. After a $2 \frac{1}{2}-\mathrm{h}$ incubation at $0^{\circ} \mathrm{C}$, the bound and free hormone were quantitated, and the magnitude of specific saturable hormone binding was determined at each [ $\left.{ }^{125} \mathrm{I}\right]$ hormone concentration as described in Methods.

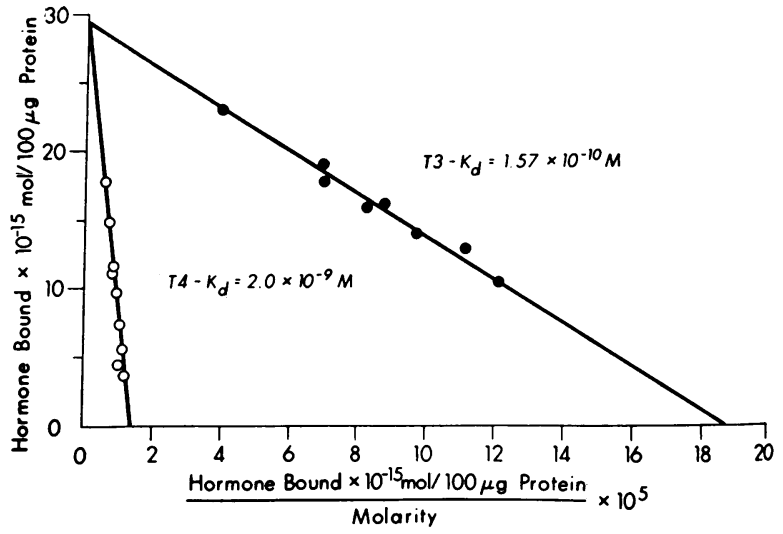

FIgURE 10 Scatchard analysis of binding of $\left[{ }^{125} \mathrm{I}\right] \mathrm{T} 3$ and [ $\left.{ }^{25} \mathrm{I}\right] \mathrm{T} 4$ with rat liver nuclear extract in vitro. Nuclear extracts of rat liver (65 $\mu \mathrm{g}$ protein) were incubated with various concentrations of $\left[{ }^{125} \mathrm{I}\right] \mathrm{T} 3$ and $\left[{ }^{125} \mathrm{I}\right] \mathrm{T} 4$. Nuclear extract at each [ $\left.{ }^{120} \mathrm{I}\right]$ hormone concentration was also incubated with a 200-fold molar excess of the respective nonradioactive hormone. After a $2 \frac{1}{2}-\mathrm{h}$ incubation at $0^{\circ} \mathrm{C}$, the bound and free hormone were quantitated, and the magnitude of specific saturable hormone binding was determined at each [ $\left.{ }^{120} \mathrm{I}\right]$ hormone concentration as described in Methods. Each point represents the mean of four determinations, and each determination did not vary more than $12 \%$ from the mean.

With intact $\mathrm{GH}_{1}$ cells, both $\mathrm{T} 3$ and $\mathrm{T} 4$ appeared to bind with the same moiety in the nucleus, and nonradioactive T3 completely inhibited $\left[{ }^{125} \mathrm{I}\right] \mathrm{T} 4$ nuclear binding (8). If $\left[{ }^{125} \mathrm{I}\right] \mathrm{T} 3$ and $\left[{ }^{125} \mathrm{I}\right] \mathrm{T} 4$ bind to identical moieties in the nuclear extract, the binding of each $\left[{ }^{125} \mathrm{I}\right]$ hormone should be equally inhibited by either nonradioactive $\mathrm{T} 3$ or $\mathrm{T} 4$.

We examined this with $\mathrm{GH}_{1}$ cell nuclear extract. Nonradioactive T3 and T4 inhibited $\left[{ }^{125} \mathrm{I}\right] \mathrm{T} 3$ binding to the same degree, and both $\mathrm{T} 3$ and $\mathrm{T} 4$ also equally inhibited $\left[{ }^{125} \mathrm{I}\right] \mathrm{T} 4$ binding with nuclear extract. Chromatography of the bound $\left[{ }^{125} \mathrm{I}\right] \mathrm{T} 3$ and the $\left[{ }^{125} \mathrm{I}\right] \mathrm{T} 4$ indicated that the $\left[{ }^{125} \mathrm{I}\right]$ hormone that was inhibited by nonradioactive $\mathrm{T} 3$ or $\mathrm{T} 4$ was $\left[{ }^{125} \mathrm{I}\right] \mathrm{T} 3$ and $\left[{ }^{125} \mathrm{I}\right] \mathrm{T} 4$, respectively.

These results suggest that $\mathrm{T} 3$ and $\mathrm{T} 4$ associate with identical binding moieties in the solubilized nuclear extract. Only by isolation and purification of the nuclear binding activity, however, can it be definitively determined whether $\mathrm{T} 3$ and $\mathrm{T} 4$ bind to an identical binding moiety in the nucleus.

Binding of $\left[{ }^{125} I\right] T 3$ and $\left[{ }^{125} I\right] T 4$ with $G H_{1}$ cell cytosol. Our previous studies indicated that incubation of intact $\mathrm{GH}_{1}$ cells with nonradioactive $\mathrm{T} 3$ resulted in an apparent increase in detectable $\left[{ }^{125} \mathrm{I}\right] \mathrm{T} 3$ binding with a second incubation with isolated nuclei (8). This suggested the possibility that the number of high-affinity nuclear binding sites was not fixed but increased after 


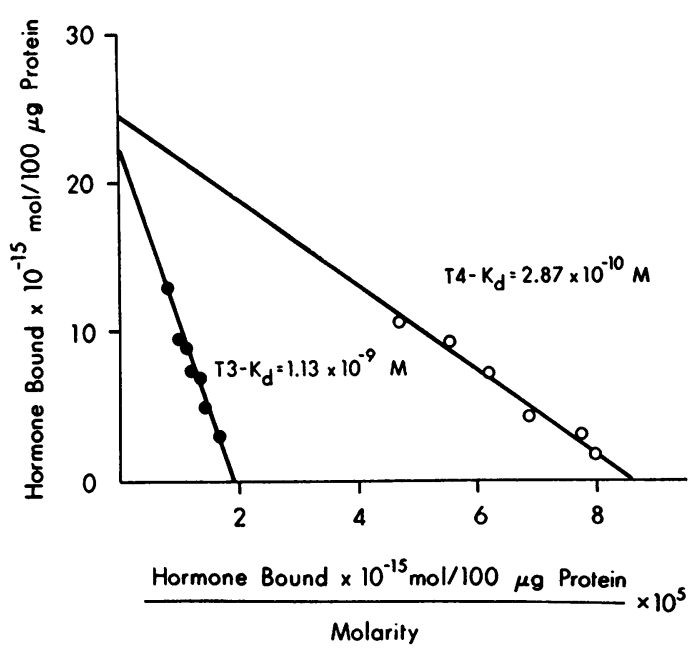

Figure 11 Scatchard analysis of binding of [ $\left.{ }^{190} \mathrm{I}\right] \mathrm{T} 3$ and [ $\left.{ }^{125} \mathrm{I}\right] \mathrm{T} 4$ with cytosol of $\mathrm{GH}_{1}$ cells. Cytosol ( $50 \mu \mathrm{g}$ protein) prepared from $\mathrm{GH}_{1}$ cells was incubated with various concentrations of $\left[{ }^{125} \mathrm{I}\right] \mathrm{T} 3$ and $\left.{ }^{120} \mathrm{I}\right] \mathrm{T} 4$. The cytosol at each [ $\left.{ }^{120} \mathrm{I}\right]$ hormone concentration was also incubated with a 200fold molar excess of the respective nonradioactive hormone. After a $2 \frac{1}{2}$-h incubation at $0^{\circ} \mathrm{C}$, the bound and free hormone were quantitated, and the magnitude of specific saturable hormone binding was determined at each [ $\left.{ }^{125} \mathrm{I}\right]$ hormone concentration as described in Methods. Each point represents the mean of three determinations, and each determination did not vary more than $10 \%$ from the mean.

incubation of intact cells with hormone. This indirectly implied that the mechanism of thyroid hormone binding to nuclei with intact cells might occur by molecular mechanisms similar to that reported with steroid hormones (23). By this mechanism, T3 or T4 would initially interact with a cytosol receptor, and after a temperature-dependent conformational change, the hormone-receptor complex would associate with nuclear acceptor sites. Our prior observations, however, were more consistent with the possibility that thyroid hormone stabilized the nuclear binding activity sufficiently to permit an exchange reaction with $\left[{ }^{125} \mathrm{I}\right] \mathrm{T} 3$ in the second incubation with isolated nuclei.

We examined the characteristics of $\left[{ }^{125} \mathrm{I}\right] \mathrm{T} 3$ and $\left.{ }^{[25} \mathrm{I}\right] \mathrm{T} 4$ binding with cytosol of $\mathrm{GH}_{1}$ cells to determine whether a cytosol binding activity might be related to the nuclear binding of the thyroid hormones. The timecourse of $\left[{ }^{125} \mathrm{I}\right] \mathrm{T} 3$ and $\left[{ }^{225} \mathrm{I}\right] \mathrm{T} 4$ with $\mathrm{GH}_{1}$ cell cytosol was examined at $0^{\circ} \mathrm{C}$ and found to be similar to that determined with nuclear extract (Fig. 5). Fig. 11 illustrates an estimation of the $K_{d}$ for $\left[{ }^{125} \mathrm{I}\right] \mathrm{T} 3$ and $\left[{ }^{205} \mathrm{I}\right] \mathrm{T} 4$ binding with cytosol after a 2 -h incubation at $0^{\circ} \mathrm{C}$. The estimated $K_{d}$ for hormone binding was $2.87 \times$ $10^{-10} \mathrm{M}$ for T4 and $1.13 \times 10^{-8} \mathrm{M}$ for T3. The $K_{d}$ for $\mathrm{T} 4$ or $\mathrm{T} 3$ was not changed by $0.4 \mathrm{KCl}$.
The total number of estimated cytosol binding sites were similar for $\mathrm{T} 3$ and $\mathrm{T} 4$. In addition, the binding of $\left[{ }^{125} \mathrm{I}\right] \mathrm{T} 3$ as well as $\left[{ }^{205} \mathrm{I}\right] \mathrm{T} 4$ were each completely inhibited with either nonradioactive T3 or T4. This suggested that $\left[{ }^{120} \mathrm{I}\right] \mathrm{T} 3$ and $\left[{ }^{128} \mathrm{I}\right] \mathrm{T} 4$ associated with identical binding moieties in the cytosol fraction.

These results in cytosol contrast with our observations of the relative affinities of T3 and T4 binding with nuclei of intact $\mathrm{GH}_{1}$ cells $(7,8)$ and nuclear extracts of $\mathrm{GH}_{1}$ cells and rat liver. The 10-fold greater affinity for $\mathrm{T} 4$ compared to $\mathrm{T} 3$ in cytosol also contrasts with the observed greater intrinsic biologic activity of T3 determined with cultured $\mathrm{GH}_{1}$ cells and intact rats $(6,24)$. This suggests that the observed cytosol binding activity is likely not related to the nuclear binding activity nor to the observed biologic effects of the thyroid hormones. The results do not exclude the possibility, however, that a cytosol receptor not detected by our in vitro determination is involved in the action of the thyroid hormones. Our observations with $\mathrm{GH}_{1}$ cell cytosol also suggest that the nuclear binding activity determined with isolated nuclei and nuclear extracts of $\mathrm{GH}_{1}$ cells and rat liver does not result from a nonspecific association of cytosol components with nuclei during the isolation procedure.

\section{DISCUSSION}

Our previous studies indicated that putative nuclear receptors for the thyroid hormones could be detected if $\left[{ }^{25} \mathrm{I}\right] \mathrm{T} 3$ or $\left[{ }^{205} \mathrm{I}\right] \mathrm{T} 4$ were incubated with intact $\mathrm{GH}_{1}$ cells in culture $(7,8)$. The estimated $K_{d}$ for nuclear binding with whole cells was $2.9 \times 10^{-11} \mathrm{M}$ for T3 and $2.5 \times 10^{-10} \mathrm{M}$ for $\mathrm{T} 4(7,8)$. In addition, the total number of estimated nuclear binding sites were similar for both hormones, and the binding of one hormone was completely inhibited by the other. This suggested that both $\mathrm{T} 3$ and $\mathrm{T} 4$ associate with the same binding moiety in the nucleus. These estimated $K_{d}$ values for nuclear binding in whole cells were sufficiently similar to the estimated free hormone concentrations which induced a half-maximal increase on $\mathrm{GH}_{1}$ cell replication to suggest that these high-affinity nuclear binding activities functioned as hormonal receptors $(6,8)$. To demonstrate that high-affinity nuclear binding is not unique to rat tissue, but likely reflects a biological interaction which can be studied with human tissue, we also examined the nuclear binding of $\left[{ }^{125} \mathrm{I}\right] \mathrm{T} 3$ with human lymphocytes (25). The estimated $K_{d}$ for T3 nuclear binding after incubation with intact lymphocytes was $3.08 \times 10^{-11} \mathrm{M}(25)$. This value is virtually identical to that determined with cultured $\mathrm{GH}_{1}$ cells.

In order to further relate our observations in cultured $\mathrm{GH}_{1}$ cells to the possible actions of thyroid hormone 
in vivo, we developed a system to quantitate the association of thyroid hormones by incubation of $\left[{ }^{125} \mathrm{I}\right]$ hormone directly with isolated nuclei in vitro $(7,8,10)$. The estimated $K_{d}$ for T3 binding in vitro was $1.65 \times$ $10^{-10} \mathrm{M}$ for isolated $\mathrm{GH}_{1}$ cell nuclei and $2.1 \times 10^{-10} \mathrm{M}$ for isolated rat liver nuclei (10). The total number of binding sites per nucleus $(8,000)$ was identical with isolated $\mathrm{GH}_{1}$ cell nuclei and rat liver nuclei in vitro and was also the same as that estimated with intact $\mathrm{GH}_{1}$ cells (10). The fact that the total number of estimated high-affinity sites were the same with intact cells and isolated nuclei suggested that the binding activity determined under in vitro conditions represented the same nuclear binding activity determined with whole cells. The fivefold lower affinity estimated in vitro was likely due to the obvious differences in the nuclear environmental conditions of intact cells and the isolated nuclear binding assay.

The estimated $K_{d}$ for T3 binding to isolated nuclei, which we estimated in vitro (10), was also similar to that determined by Oppenheimer, Schwartz, Koerner, and Surks after injection of hormone in intact rats (26). Although estimation of hormonal affinity in vivo cannot be analyzed under equilibrium conditions, the similarity of the binding affinities also suggests that the nuclear binding activity which we observe in vitro is the same as observed in vivo.

We have previously reported that the nuclear binding activity extracted from $\mathrm{GH}_{1}$ cell nuclei, as well as rat liver and rat kidney nuclei, could reassociate with $\left[{ }^{125} \mathrm{I}\right] \mathrm{T} 3$ under in vitro conditions $(8,12)$.

In our current studies, we have demonstrated that the nuclear binding activity from $\mathrm{GH}_{1}$ cells and rat liver can be extracted from nuclei with no apparent change in hormonal affinity.

The fact that the binding activity did not sediment after centrifugation at $150,000 \mathrm{~g}$ for $3 \mathrm{~h}$ indicates that the extracted binding protein is likely in a soluble form. This does not rule out the possibility that the binding activity might remain association with small fragments of nucleic acid.

The estimated $K_{d}$ for T3 binding with nuclear extract was $1.8 \times 10^{-10} \mathrm{M}$ for $\mathrm{GH}_{1}$ cells and $1.57 \times 10^{-10}$ $\mathrm{M}$ for rat liver. These $K_{d}$ values are virtually identical to those determined with isolated $\mathrm{GH}_{1}$ cell and rat liver nuclei in vitro (10). In addition, the affinity for $\mathrm{T} 4$ binding with both nuclear extracts was approximately $1 / 10$ th of that observed for T3. The 10 -fold greater affinity for T3 compared to T4, as well as the fact that either hormone can inhibit the binding of the other in vitro, is identical to our previous observations on the nuclear binding with intact $\mathrm{GH}_{1}$ cells (8). The 10 -fold greater affinity for $\mathrm{T} 3$ compared to $\mathrm{T} 4$ with the nuclear extract also agrees with our observations that $\mathrm{T} 4$ has approximately $1 / 10$ th the intrinsic biologic activity of T3 (6).

To further document that the binding of $\mathrm{T} 3$ and $\mathrm{T} 4$ with nuclear extract in vitro reflects a biologically relevant association with hormonal receptors, we also examined the cross-reaction with a variety of hormonal analogs with $\left[{ }^{125} \mathrm{I}\right] \mathrm{T} 3$ in vitro (27). The extent of crossreaction with $\mathrm{GH}_{1}$ cell and rat liver nuclear extract was: $3,5,3^{\prime}$-triiodo-D-thyronine $(22 \%), 3,5,3^{\prime}, 5^{\prime}$ tetraiodo-D-thyronine $(1.7 \%), 3,5$-diiodo-L-thyronine $(0.36 \%)$, and $\mathrm{L}$-thyronine $(0.23 \%)$. These relative affinities are virtually identical to the relative differences in the biologic activity of the hormonal analogs with cultured $\mathrm{GH}_{1}$ cells (6). In addition, these observations on the cross-reactivity of the hormonal analogs with T3 in vitro are similar to the observations of Oppenheimer, Schwartz, Dillman, and Surks after injection of the hormonal analogs in vivo (28).

This further supports our conclusion that the in vitro association of $\mathrm{T} 3$ and $\mathrm{T} 4$ with nuclear extract reflects a biologically relevant association with hormonal receptors and that the in vitro binding activity is the same moiety as that observed under in vivo conditions.

We examined the biochemical nature of the nuclear binding activity after association of $\left[{ }^{125} \mathrm{I}\right] \mathrm{T} 3$ with extract in vitro. Chromatographic analysis on Bio-Rex 70 (21), which can separate basic histone proteins from acidic nonhistone proteins, demonstrated that the binding activity in vitro was not a histone protein. Similar observations were also made with solubilized nuclear binding activity prepared after incubation of intact $\mathrm{GH}_{1}$ cells with $\left[{ }^{125} \mathrm{I}\right] \mathrm{T} 3$. In addition, the sensitivity of the binding activity in vitro to trypsin and Pronase, and not to DNase or RNase, indicated that the binding activity was a protein. This, along with the observation that the binding activity was not a basic protein, suggested that the in vitro binding activity was a nonhistone protein.

Surks et al. previously reported that the binding activity extracted after nuclear binding of $\left[{ }^{125} \mathrm{I}\right] \mathrm{T} 3$ in vivo was a nonhistone protein (11). This was based on a progressive increase of extractability of the T3-macromolecular complex over the $\mathrm{pH}$ range of $6.0-8.5$ and relatively less inactivation of the complex by trypsin compared to chymotrypsin or Pronase. Similar observations after hormone binding in vivo were also reported by DeGroot, Refetoff, Strausser, and Barsano (29).

Our studies, however, are in contrast with Surks et al. (11) and DeGroot et al. (29), in that these investigators reported that specific association of $\left[{ }^{125} \mathrm{I}\right]$ T3 did not occur with nuclear extract in vitro. This 
might have resulted from significant proteolytic activity in the extract due to the different methodology of nuclear isolation or to the composition of the incubation mixture used to quantitate the nuclear binding activity.

Cytosol-binding proteins for the thyroid hormones have been previously reported by several investigators. Hamada, Torizuka, Miyake, and Fukase reported that liver cytosol contained distinct binding proteins for T3 and T4 (30). Spaulding and Davis reported that the liver cytosol of male rats contains two distinct proteins with estimated mol wts of 95,000 and 45,000 (31). Sufi, Toccafondi, Malan, and Ekins reported that the cytosol of porcine anterior pituitary contained binding proteins for $\mathrm{T} 3$ and $\mathrm{T} 4$ (32). The estimated $K_{d}$ for binding was $7 \times 10^{-10} \mathrm{M}$ for $\mathrm{T} 4$ and $2.5 \times 10^{-6} \mathrm{M}$ for T3 (32). The greater affinity for $\mathrm{T} 4$ compared to $\mathrm{T} 3$ in porcine pituitary cytosol is similar to our observations with cytosol of $\mathrm{GH}_{1}$ cells. In $\mathrm{GH}_{1}$ cell cytosol the estimated $K_{a}$ for hormone binding was $2.87 \times 10^{-10}$ $\mathrm{M}$ for $\mathrm{T} 4$ and $1.13 \times 10^{-8} \mathrm{M}$ for $\mathrm{T} 3$. In addition, the fact that $\mathrm{GH}_{1}$ cell cytosol contained a similar number of binding sites for T3 and T4 and that either hormone can inhibit the binding of the other suggested that both hormones associate the same binding species. Although the cells were extensively washed free of media, we cannot exclude the possibility that the cytosol binding activity represents serum binding protein which was taken up or associated with the surface of the cells. The marked difference in affinity for T3 and T4 with the nuclear extract when compared with the cytosol binding activity, however, indicates that binding with nuclei or nuclear extract in vitro does not reflect association of the observed cytosol components with nuclei during tissue fractionation.

The precise biologic role of the cytosol binding activity is not clear. The 10 -fold greater affinity for T4 compared to $\mathrm{T} 3$ are inversely related to observed intrinsic biologic activity of these hormones $(6,24)$. A significant question relates as to whether the thyroid hormones associate directly with nuclear receptors in whole cells or require an initial interaction with a cytosol binding protein. Our previous observations with intact $\mathrm{GH}_{1}$ cells did not demonstrate a kinetic transfer of cytosol-bound $\left[{ }^{125} \mathrm{I}\right] \mathrm{T} 3$ to nuclei (8). Cytosol binding activities with intact $\mathrm{GH}_{1}$ cells similar in affinity for $\mathrm{T} 3$ as nuclear sites were also not detected. These findings support the concept that T3 or T4 associate directly with binding sites in the cell nucleus without a primary interaction in the cell cytosol.

It remains possible, however, that a putative biologically relevant cytosol receptor is involved in the action of the thyroid hormones. This binding activity might be unstable or require specific activation conditions for association with thyroid hormone in vitro. Alterna- tively, the cytosol binding activity determined in vitro might function as a factor which converts $\mathrm{T} 4$ to $\mathrm{T} 3$ in vivo.

Our current studies indicate that high-affinity nuclear binding proteins for $\mathrm{T} 3$ and $\mathrm{T} 4$ can be isolated in a soluble and stable form with no apparent change in hormonal affinity after dissociation from nuclei. The binding activity has characteristics of a nonhistone protein, and the association with $\mathrm{T} 3$ and $\mathrm{T} 4$ as well as with hormonal analogs suggests that the binding activity determined in vitro likely functions as a receptor for the thyroid hormones in vivo. Extensions of these in vitro studies should allow for resolution of the mechanisms of action of the thyroid hormones at the molecular level.

\section{ACKNOWLEDGMENTS}

This study was supported by American Cancer Society Grant BC-123a and NIH grant AM 16636.

\section{REFERENCES}

1. Wolff, E. C., and J. Wolff. 1964. The mechanism of action of the thyroid hormones. In The Thyroid Gland. R. Pitt-Rivers and W. R. Trotter, editors. Butterworth and Co. (Publishers) Ltd., London. 1: 237-282.

2. Hoch, F. L. 1962. Biochemical actions of thyroid hormones. Physiol. Rev. 42: 605-673.

3. Hamburgh, M., L. A. Mendoza, J. F. Burkart, and F. Weil. 1971. Thyroid-dependent processes in the developing nervous system. In Hormones in Development. M. Hamburgh and E. J. W. Barrington, editors. Appleton-Century-Crofts, New York. 403-415.

4. Frieden, E., and J. J. Just. 1970. Hormonal responses in amphibian metamorphosis. In Biochemical Actions of Hormones. G. Litwack, editor. Academic Press, Inc., New York. 1: 1-51.

5. Tata, J. R., and C. C. Widnell. 1966. Ribonucleic acid synthesis during the early action of the thyroid hormones. Biochem. J. 98: 604-620.

6. Samuels, H. H., J. S. Tsai, and R. Cintron. 1973. Thyroid hormone action: a cell-culture system responsive to physiological concentrations of thyroid hormones. Science (Wash. D. C.). 181: 1253-1256.

7. Samuels, H. H., and J. S. Tsai. 1973. Thyroid hormone action: demonstration of nuclear receptors and transcriptional control in cell culture. J. Clin. Invest. 52: 72a. (Abstr.)

8. Samuels, H. H., and J. S. Tsai. 1973. Thyroid hormone action in cell culture: demonstration of nuclear receptors in intact cells and isolated nuclei. Proc. Natl. Acad. Sci. U. S. A. 70: 3488-3492.

9. Oppenheimer, J. H., D. Koerner, H. L. Schwartz, and M. I. Surks. 1972. Specific-nuclear triiodothyronine binding sites in rat liver and kidney. J. Clin. Endocrinol. Metab. 35:330-333.

10. Samuels, H. H., and J. S. Tsai. 1974. Thyroid hormone action: demonstration of similar receptors in isolated nuclei of rat liver and cultured $\mathrm{GH}_{1}$ cells. J. Clin. In vest. 53 : 656-659. 
11. Surks, M. I., D. Koerner, W. Dillman, and J. H. Oppenheimer. 1973. Limited capacity binding sites for Ltriiodothyronine in rat liver nuclei: localization to the chromatin and partial characterization of the L-triiodothyronine-chromatin complex. J. Biol. Chem. 248: 7066-7072.

12. Samuels, H. H., J. S. Tsai, and J. Casanova. 1974. Thyroid hormone action: in vitro demonstration of putative receptors in isolated nuclei and soluble nuclear extracts. Science (Wash. D. C.). 184 : 1188-1191.

13. Green, W. L. 1972. Separation of iodo compounds in serum by chromatography on sephadex columns. $J$. Chromatogr. 72 : 83-91.

14. Bellabarba, D., R. E. Peterson, and K. Sterling. 1968. An improved method for chromatography of iodothyronines. J. Clin. Endocrinol. Metab. 28: 305-307.

15. Mitsuma, T., J. Colucci, L. Shenkman, and C. S. Hollander. 1972. Rapid simultaneous radioimmunoassay for triiodothyronine and thyroxine in unextracted serum. Biochem. Biophys. Res. Commun. 46: 2107-2113.

16. Lowry, O. H., N. J. Rosebrough, A. L. Farr, and R. J. Randall. 1951. Protein measurement with folin phenol reagent. J. Biol. Chem. 193: 265-275.

17. Burton, K. 1956. A study of the conditions and mechanism of the diphenylamine reaction for the colorimetric estimation of deoxyribonucleic acid. Biochem. J. 62: 315-323.

18. Schneider, W. C. 1957. Determination of nucleic acids in tissues by pentose analysis. Methods Enzymol. 3: 680-684.

19. Hymer, W. C., and E. L. Kuff. 1964. Isolation of nuclei from mammalian tissues through the use of Triton X-100. J. Histochem. Cytochem. 12: 359-363.

20. Scatchard, G. 1949. The attraction of proteins for small molecules and ions. Ann. N. Y. Acad. Sci. $51: 660-672$.

21. van den Broek, H. W. J., L. D. Noodén, J. S. Sevall, and J. Bonner. 1973. Isolation, purification, and fractionation of nonhistone chromosomal proteins. Biochemistry. $12: 229-236$.

22. Georgiev, G. P., L. N. Anaieva, and J. V. Kozlov. 1966. Stepwise removal of protein from a deoxyribonucleoprotein complex and de-repression of the genome, J. Mol. Biol. 22 : 365-371.
23. O'Malley, B. W., and A. R. Means. 1974. Female steroid hormones and target cell nuclei. Science (Wash. D. C.). 183: 610-620.

24. Money, W. L., S. Kumaoka, R. L. Kroc, and R. W. Rawson. 1960. Comparative effects of thyroxine analogues in experimental animals. Ann. N. Y. Acad. Sci. 86: $512-544$.

25. Tsai, J. S., and H. H. Samuels. 1974. Thyroid hormone action: demonstration of putative nuclear receptors in human lymphocytes. J. Clin. Endocrinol. Metab. $38: 919-922$.

26. Oppenheimer, J. H., H. L. Schwartz, D. H. Koerner, and M. I. Surks. 1973. Nuclear receptor sites for triiodothyronine $\left(\mathrm{T}_{8}\right)$ in rat liver; kinetics of binding and evidence for the induction of new binding sites in the hyperthyroid state. J. Clin. Invest. 52: 62a. (Abstr.)

27. Samuels, H. H., and J. S. Tsai. 1974. In vitro association of thyroid hormone and hormonal analogs with solubilized nuclear receptors of rat liver and cultured $\mathrm{GH}_{1}$ cells. Program of the 56th Annual Meeting of the Endocrine Society, Atlanta, Ga. A-94.

28. Oppenheimer, J. H., H. L. Schwartz, W. Dillman, and M. I. Surks. 1973. Effect of thyroid hormone analogues on the displacement of ${ }^{125} \mathrm{I}-\mathrm{L}$-triiodothyronine from hepatic and heart nuclei in vivo: possible relationship to hormonal activity. Biochern. Biophys. Res. Commun. 55: 544-555.

29. DeGroot, L. J., S. Refetoff, J. Strausser, and C. Barsano. 1973. Characterization of triiodothyronine nuclear binding protein from rat liver. Program of The 49th Meeting of The American Thyroid Association, Seattle, Wash. T-14.

30. Hamada, S., K. Torizuka, T. Miyake, and M. Fukase. 1970. Specific binding proteins of thyroxine and triiodothyronine in liver soluble proteins. Biochim. Biophys. Acta. 201 : 479-492.

31. Spaulding, S. W., and P. J. Davis. 1971. Thyroxine binding to soluble proteins in rat liver and its sex dependence. Biochim. Biophys. Acta. 229: 279-283.

32. Sufi, S. B., R. S. Toccafondi, P. G. Malan, and R. P. Ekins. 1973. Binding of thyroid hormones to a soluble fraction from porcine anterior pituitary. J. Endocrinol. $58: 41-52$. 